\title{
Olefin metathesis in air
}

\author{
Lorenzo Piola ${ }^{1}$, Fady Nahra ${ }^{1}$ and Steven P. Nolan ${ }^{* 2}$
}

\author{
Review \\ Address: \\ ${ }^{1}$ EaStCHEM, School of Chemistry, University of St Andrews, St \\ Andrews, KY16 9ST, UK and ${ }^{2}$ Chemistry Department, College of \\ Science, King Saud University, Riyadh 11451, Saudi Arabia \\ Email: \\ Steven P. Nolan* - stevenpnolan@gmail.com \\ * Corresponding author \\ Keywords: \\ air stability; catalysis; olefin metathesis; RCM; ROMP; ruthenium
}

\author{
Beilstein J. Org. Chem. 2015, 11, 2038-2056. \\ doi:10.3762/bjoc. 11.221 \\ Received: 21 July 2015 \\ Accepted: 13 October 2015 \\ Published: 30 October 2015 \\ This article is part of the Thematic Series "Progress in metathesis \\ chemistry II". \\ Guest Editor: K. Grela \\ (C) 2015 Piola et al; licensee Beilstein-Institut. \\ License and terms: see end of document.
}

\begin{abstract}
Since the discovery and now widespread use of olefin metathesis, the evolution of metathesis catalysts towards air stability has become an area of significant interest. In this fascinating area of study, beginning with early systems making use of high oxidation state early transition metal centers that required strict exclusion of water and air, advances have been made to render catalysts more stable and yet more functional group tolerant. This review summarizes the major developments concerning catalytic systems directed towards water and air tolerance.
\end{abstract}

\section{Introduction}

Transition metal-catalyzed alkene metathesis [1-10], which involves a fragment exchange between alkenes, is nowadays one of the most used strategies for the formation of carbon-carbon bonds. This area of study began with a "black box" approach for catalysts formation in polymerization of olefins. In recent years, metathesis-type reactions have emerged as universal strategies, employed in many fields of organic chemistry: from polymer chemistry [11-18] to natural product [19-21] and fine chemical syntheses [3,22-25]. Its importance led to the 2005 Nobel Prize in chemistry being awarded to Yves Chauvin, Richard Schrock and Robert Grubbs, who developed and studied this reaction [26]. Its wide adoption in organic reac- tions, where the use of inert and dry conditions are not always desirable, has led to efforts to develop new catalytic systems that enable this transformation in the presence of air and water [27]. However, this field of research has suffered a slow growth and only recently, an increasing number of research groups have started to seriously focus on testing metathesis catalysts in the presence of air and water. This is a way to gauge catalyst stability but also to potentially bring operational simplicity to this now widespead assembly strategy.

In this review, we summarize improvements associated with the stability of well-defined metathesis homogeneous systems 
towards the presence of air and water in the alkene metathesis and hopefully raise the awareness of the significant tolerance of standard metathesis catalysts to these conditions.

\section{Review}

\section{Well-defined ruthenium catalysts}

Although well-defined early transition metal-based catalysts formed the basis of early metathesis reactions and can be thought of as the forefathers of modern metathesis catalysts [27$30]$, these all showed poor tolerance towards air and water, because of their high oxophilicity $[3,8,9,16,27]$. To date, there are no examples of their use in the presence of air.

To overcome the sensitivity problems exhibited by early transition-based catalysts, late transition metals, which do not exhibit high oxophilicity, appeared as the most promising candidates for reactions performed in air.

Indeed in 1988, Grubbs and Novak reported that not only ruthenium was an interesting candidate for olefin metathesis, but also that reactions were successfully conducted in water [31,32]. They discovered that $\mathrm{Ru}\left(\mathrm{H}_{2} \mathrm{O}\right)_{6}(\text { tos })_{2}$ could polymerize 7-oxanorbonene $\mathbf{1}$ in water under air (Scheme 1).

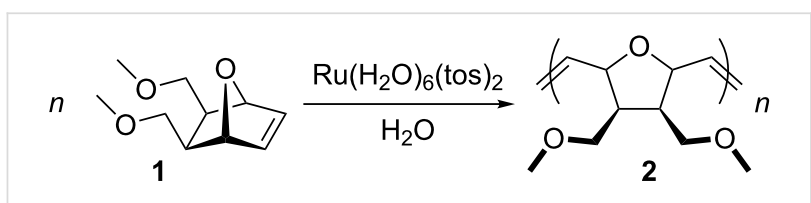

Scheme 1: Polymerization of 7-oxanorbornene in water.

In 1991, Marciniec and Pietraszuck reported the catalytic activity of $\mathrm{RuCl}_{2}\left(\mathrm{PPh}_{3}\right)_{3}$ in the self-metathesis of siliconcontaning olefins. The reactions were performed with $1 \mathrm{~mol} \%$ of $\mathrm{Ru}$ at $150{ }^{\circ} \mathrm{C}$ in air, under solvent-free conditions for several days, to afford 1,2-bis(silyl)ethenes in moderate to good yields [33]. Reactions without oxygen showed no conversion, highlighting the important role that the latter plays in the activation of the catalyst.

In 1992, Grubbs and co-workers synthesized the first welldefined ruthenium(II) complex (5, Scheme 2 ) bearing a carbene moiety, able to perform ring-opening metathesis polymerization (ROMP) reactions of low-strained olefins [34,35] and ringclosing metathesis (RCM) reactions of functionalized dienes [36]. In the solid state, this complex was reported to be indefinitely stable under inert atmosphere whereas it could survive for only several minutes in air. In solution, it was stable in several degassed organic solvents, even in the presence of water or $\mathrm{HCl}$ [35].

Exchanging $\mathrm{PPh}_{3}$ with $\mathrm{PCy}_{3}$ increased significantly the activity of the catalyst 6 (Scheme 2), which then was capable of polymerizing unstrained cyclic olefins and to perform reactions with acyclic olefins [37]. Subsequent variations showed that larger and more basic phosphine ligands led to improved activity, and that an order of activity could be established as $\mathrm{PCy}_{3}>\mathrm{P}(\mathrm{iPr})_{3}$ $>>\mathrm{PP}_{3}$. Reactions had to be performed in degassed and distilled solvents under $\mathrm{N}_{2}$ atmosphere to obtain maximum yields.

\section{Grubbs' $1^{\text {st }}$ generation catalyst}

To overcome the aforementioned difficulties, Grubbs and co-workers synthesized, what has become known as the Grubbs' $1^{\text {st }}$ generation catalyst $(\mathbf{9}$, Scheme 3$)$. The reaction of $\mathrm{RuCl}_{2}\left(\mathrm{PPh}_{3}\right)_{3-4}(3)$ with phenyldiazomethane (7), followed by a phosphine exchange reaction, afforded complex 9 in high yields. Complex 9 has become the most used metathesis cata-
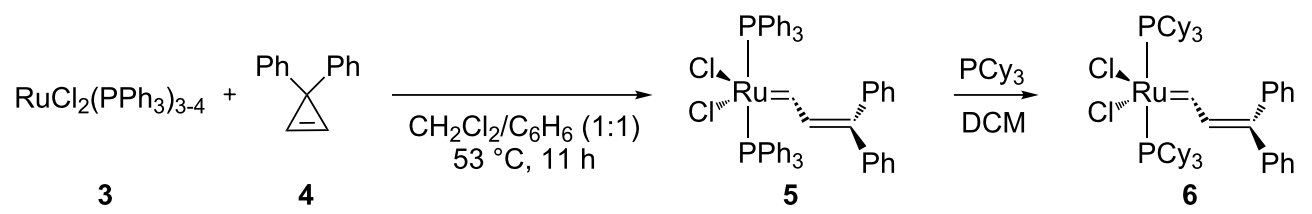

Scheme 2: Synthesis of the first well-defined ruthenium carbene.

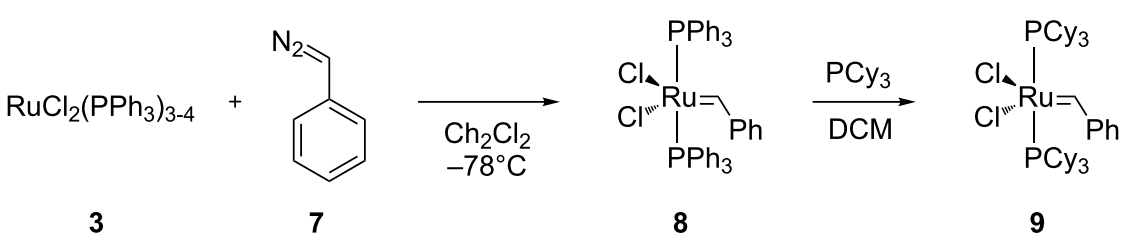


lyst, because of its good activity, relatively good stability to air (storage of 9 has been recommended to be performed under anaerobic conditions and lower temperatures), compatibility with a large variety of functional groups $[36,38]$ and because of its feasible large-scale production. So far, the use of this catalyst in air has not been reported.

\section{$2^{\text {nd }}$ generation catalyst}

The synthesis of heteroleptic complexes, bearing one $N$-heterocyclic carbene (NHC) (16-19, Figure 1) and one phosphine as ligands, represented the second crucial turning point in this chemistry. Following Herrmann's report on bis-NHC ruthenium complexes (10-15) and their low activity [39], independently and simultaneously the groups of Nolan (14) [40,41], Grubbs (15) [42-45] and Hermann [46-48] reported on the synthesis of this family of complexes. The combination of a labile phosphine group with a non-labile NHC ligand provided a significant improvement in terms of reactivity and stability. The bulky NHC provides steric protection to the metal center and its $\sigma$-donating ability stabilizes both the pre-catalyst and the catalytically operating intermediate [49]. The most active being complex 15, bearing SIMes (1,3-bis(2,4,6-trimethylphenyl)-4,5dihydroimidazol-2-ylidene, 17) as ligand, is known nowadays as the Grubbs' $2^{\text {nd }}$ generation catalyst. The increased stability of $\mathbf{1 7}$ is due to the unsaturated backbone of the NHC; the steric bulkiness on the metal center is improved and the $\sigma$-donating ability is increased compared to other NHCs.

These were the first ruthenium-based catalysts able to perform RCM reactions of tri- and tetrasubstituted olefins [42,46], crossmetathesis (CM) to afford trisubstituted olefins [44] and CM and $\mathrm{RCM}$ reactions of electron-withdrawing substituted olefins [45]. In comparison to the $1^{\text {st }}$ generation, they show a generally higher stability towards thermal degradation $[41-43,49,50]$. To date, only one example is reported where catalyst $\mathbf{1 5}$ is used in air (see following section).

\section{Hoveyda-Grubbs catalyst}

The next notable evolution in terms of higher catalyst stability came from the Hoveyda group in 1999 [51]. While performing metathesis in the presence of isopropoxystyrene (20, Scheme 4), they noticed that the reaction proceeded very slowly. They postulated that the isopropoxystyrene formed a Ru-chelate complex in situ, which would be more stable than the precatalyst used in the reaction; therefore reducing the rate of the subsequent steps. Upon synthesis and evaluation of this new Ru-chelate complex (21, Scheme 4), they noted its astonishing stability. It could be recycled after reaction via column chromatography and it could be kept in undistilled $\mathrm{CDCl}_{3}$ for 2 weeks without any noticeable decomposition [51]. The isopropoxy group stabilized the complex by chelating the Ru moiety. Decomplexation of the latter allowed the approach of the olefinic substrate. Once the reaction reached completion and the starting materials depleted, the isopropoxy group coordinated back to the Ru center, allowing for the recycling of the catalyst. However, it should be mentioned that this increased stability diminished the activity of $\mathbf{2 1}$ when compared to 15 [52].

In 2000, Dowden [53] and co-workers reported the use of a polystyrene-supported ruthenium complex 24 (Scheme 5); a variation of the Hoveyda-Grubbs catalyst. It could be reused up to 5 times without loss of activity and without the use of a stabilizer. The catalysts were stored and used in air with non degassed DCM, providing average to good yields, with a catalyst loading of $5 \mathrm{~mol} \%$ (Figure 2).

As complex 21, the efficiency of $\mathbf{2 4}$ is limited to terminal alkenes [54], and performs poorly in CM reactions. Soon after,

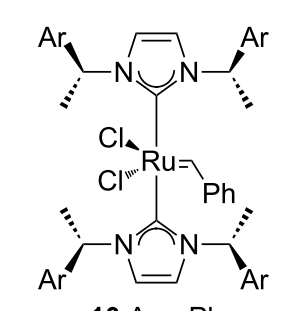

$10 \mathrm{Ar}=\mathrm{Ph}$

$11 \mathrm{Ar}=$ Naphtyl

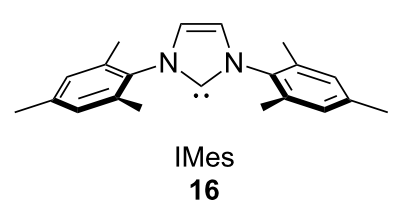

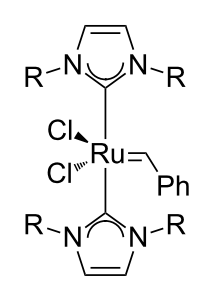

$12 \mathrm{R}=\mathrm{iPr}$

$13 \mathrm{R}=\mathrm{Cy}$

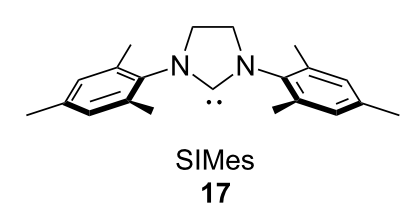

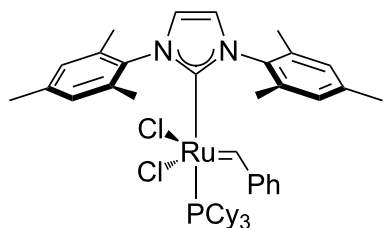

14

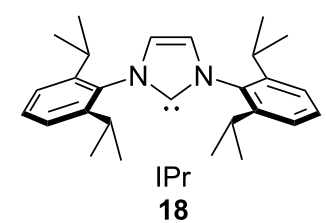

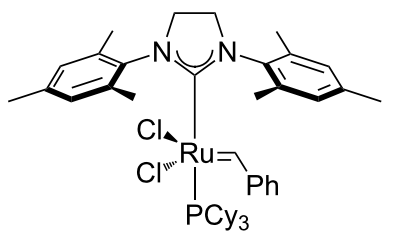

15

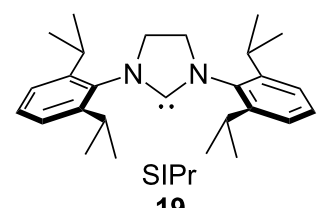

19

Figure 1: NHC-Ruthenium complexes and widely used NHC carbenes. 


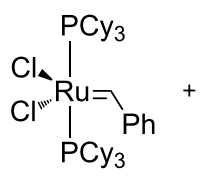

9<smiles>C=Cc1ccccc1OC(C)C</smiles>

20

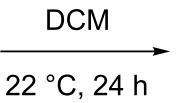

$22^{\circ} \mathrm{C}, 24 \mathrm{~h}$<smiles></smiles>

21, $67 \%$

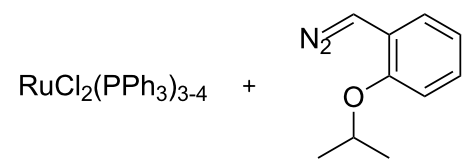

3

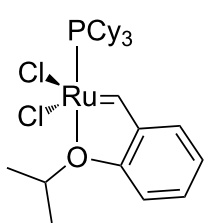

21, $76 \%$

Scheme 4: Access to 21 from the Grubbs' $1^{\text {st }}$ generation catalyst and its one-pot synthesis.<smiles>C=Cc1ccccc1OC(C)CCC(=O)NCc1ccccc1</smiles>

Scheme 5: Synthesis of supported Hoveyda-type catalyst.<smiles>C=CCN(CC=C)C(=O)OCc1ccccc1</smiles>

25<smiles>C=CCC(F)(F)CC=C</smiles>

29

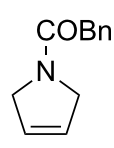

26, $91 \%$<smiles>FC1(F)CCCC1</smiles>

$30,43 \%$<smiles>C=CCC(C)(CC=C)OC(C)=O</smiles>

27<smiles>CC(=O)OC1(C)CC=CC1</smiles>

28, $77 \%$

Figure 2: Scope of RCM reactions with supported Hoveyda-type catalyst. Reaction conditions: 24 (5 mol \%), nondegassed DCM, rt, $3 \mathrm{~h}$, in air. Conversions determined by ${ }^{1} \mathrm{H}$ NMR. $\mathrm{E}=\mathrm{COOEt}$.

in 2000 , the Hoveyda-Grubbs $2^{\text {nd }}$ generation catalyst was reported (33), simultaneously, by Hoveyda (Scheme 6, entry 1) [54] and Blechert (Scheme 6, entry 2) [55] bearing a SIMes ligand instead of the phosphine.

Complex 33 was able to perform RCM of trisubstitued olefins and $\mathrm{CM}$ in high efficiency, and retained the properties of stability and recyclability.
In 2002, Hoveyda et al. reported the Hoveyda-Grubbs' $2^{\text {nd }}$ generation type catalyst 36 (Figure 3) [56]: Complex 36, bearing an unsymmetrical and chiral NHC, was active in the asymmetric ring-opening cross-metathesis ( $\mathrm{RO} / \mathrm{CM})$ in air using undistilled solvents, and yielded products with high enantiomeric excess (ee). The results where comparable to previously reported results for molybdenum-catalyzed systems [57], although the latter was used under inert conditions. 
1)

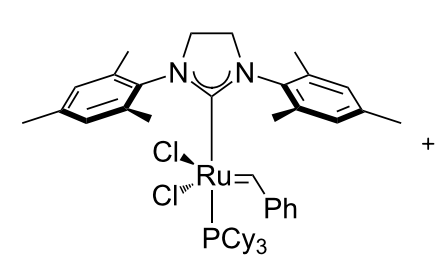

15

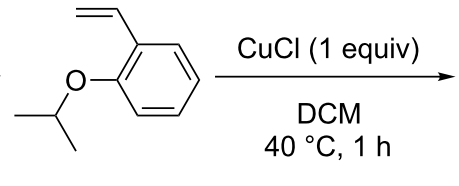

22

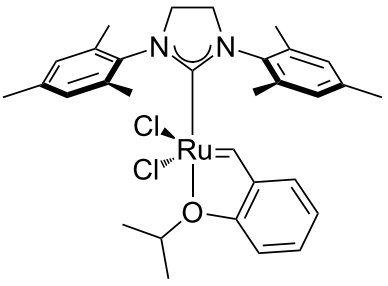

$33,85 \%$

2)<smiles>CC(C)Oc1ccccc1C=[R](Cl)(Cl)C(C)(C)C</smiles>

21

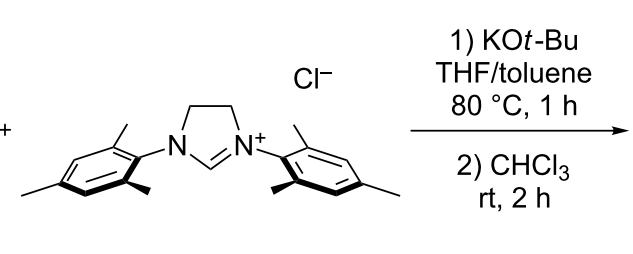

34

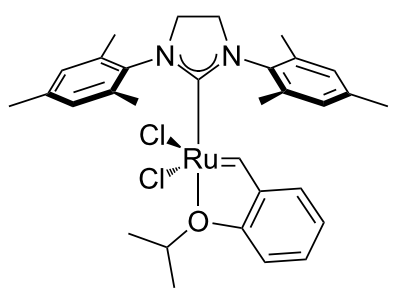

$33,75 \%$

Scheme 6: Synthesis of 33 by Hoveyda and Blechert.

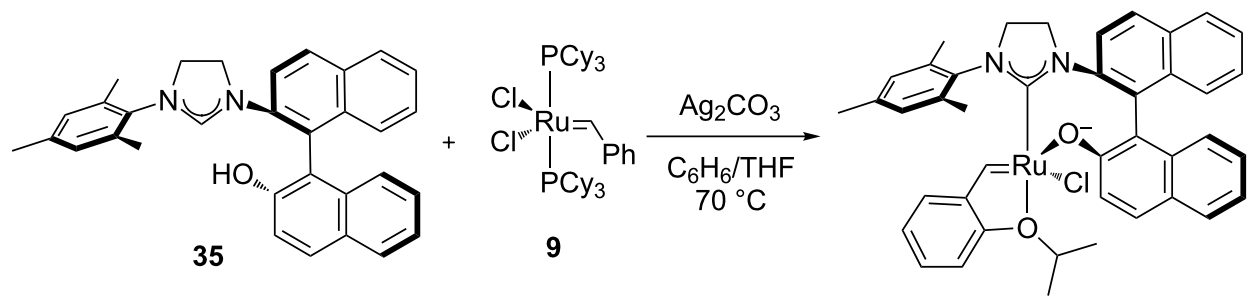

$36,52 \%$

$\underset{\mathrm{OAr}}{\stackrel{\mathrm{Ph}}{\stackrel{\text { air, undistilled THF }}{22^{\circ} \mathrm{C}, 1 \mathrm{~h}}}}$

37

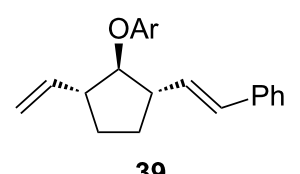

39

$96 \%$ ee, $66 \%,>98 \%$ trans (86\% recovered catalyst)

Figure 3: Synthesis of chiral Hoveyda-Grubbs type catalyst and its use in RO/CM.

In 2003, Blechert et al. reported the first systematic example of olefin metathesis in air [58]. Grubbs' $2^{\text {nd }}$ generation catalyst 15 was compared to an $m$-isopropoxy-substituted Hoveyda-Grubbs' $2^{\text {nd }}$ generation catalyst 41 (Scheme 7), using $\mathrm{MeOH}$, water and DMF as solvents. Catalyst $\mathbf{4 1}$ bore two isopropoxy groups; the first one presented as a chelating group for the ruthenium center and the second one increased the solubility of the complex in alcohol solvents and DMF.

$\mathrm{RCM}$ reactions led to high conversions with all the solvents used, employing $5 \mathrm{~mol} \%$ of $\mathbf{4 1}$ (Figure 4 and Table 1). It should be noted that catalyst $\mathbf{1 5}$ gave lower conversions when the water ratio was increased but it remained compatible with air.

The $\mathrm{CM}$ reaction, which is known to be a most difficult reaction, gave only low yield, while the $\mathrm{ROM} / \mathrm{CM}$ reaction gave a much higher yield (Figure 5). It should be noted that long reaction times were needed as well as high catalyst loadings $(5 \mathrm{~mol} \%)$ in these transformations.

In 2004, the Grela group presented some variations of the Hoveyda-Grubbs catalyst 21 [52,59,60]. They reported some modifications to the isopropoxystyrene group; a nitro group 


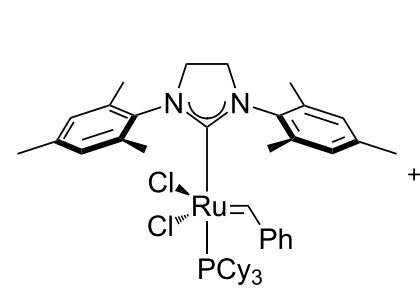

15

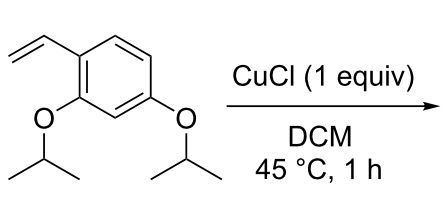

40

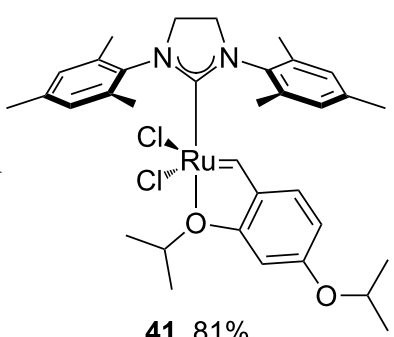

41, $81 \%$

Scheme 7: Synthesis of 41.

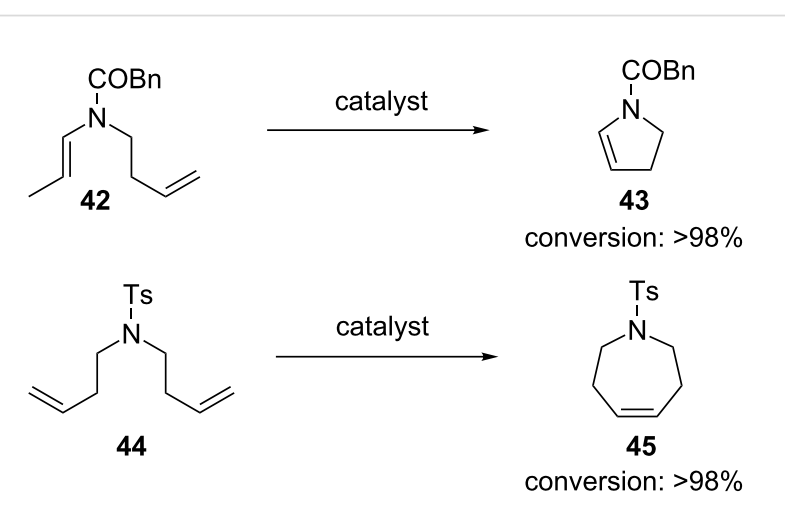

Figure 4: RCM reactions in air using 41 as catalyst. Reaction conditions: $41(5 \mathrm{~mol} \%), \mathrm{MeOH}(0.05 \mathrm{M}), 22^{\circ} \mathrm{C}, 12 \mathrm{~h}$, in air. para to the isopropoxy moiety of the carbene provided a much faster initiating catalyst (87, Figure 12) than $\mathbf{2 1}$, due to the weakening of the $\mathrm{O}-\mathrm{Ru}$ bond [59-61]. Its use in air was reported by Olszewski, Skowerski and co-workers in a comparison with other catalysts (see section on indenylidene complexes, below) [62].

Soon after, in 2006, the same group presented a variation of the Hoveyda-Grubbs $2^{\text {nd }}$ generation catalyst, bearing a quaternary ammonium group (54, Figure 6) [63]. Complex 54 was used in nondegassed mixtures of $\mathrm{MeOH} / \mathrm{EtOH}$ and water giving complete conversions in most cases, with short reaction times; although, requiring a high catalyst loading (5 mol \%). The quaternary group increased the solubility in solvent mixtures

Table 1: RCM in water and $\mathrm{MeOH}$ under air. ${ }^{\mathrm{a}}$

Solvent

Substrate

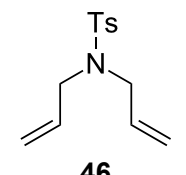

46

$\mathrm{MeOH} / \mathrm{H}_{2} \mathrm{O}(3: 1)$

$\mathrm{MeOH} / \mathrm{H}_{2} \mathrm{O}(1: 1)^{\mathrm{C}}$

$\mathrm{MeOH} / \mathrm{H}_{2} \mathrm{O}(1: 3)^{\mathrm{C}}$

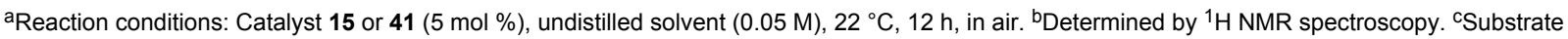
not miscible with solvent [58].

$$
\overbrace{48} \frac{\text { catalyst }}{\mathrm{MeOH} / \mathrm{H}_{2} \mathrm{O}(4: 1)(0.1 \mathrm{M})}
$$

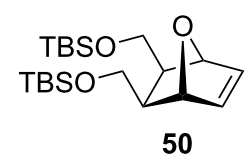

$+2$<smiles>C=CC[AsH3]</smiles>

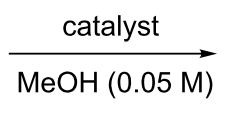

51<smiles>CC(O)CC=CCC(C)O</smiles>

$37 \%$<smiles></smiles>

Figure 5: CM-type reactions in air using 41 as catalyst. Reaction conditions: 41 (5 mol \%), $22{ }^{\circ} \mathrm{C}, 12 \mathrm{~h}$, in air. 


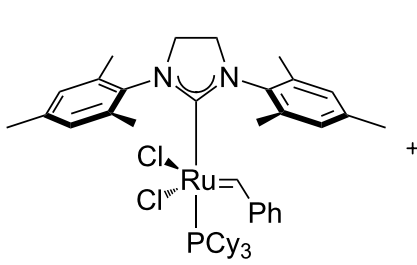

15<smiles>[3H]N(CCC=C)CCC=C</smiles>

44<smiles>[3H]N(CC#C)CC=C</smiles>

$\underset{\text { solvent }}{\stackrel{54(5 \mathrm{~mol} \%)}{\longrightarrow}}$

57

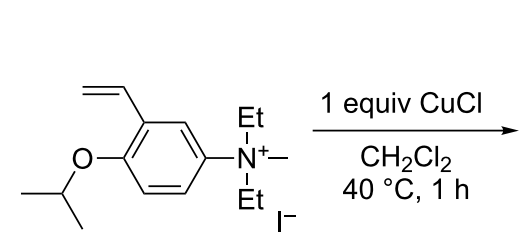

53<smiles>C#CC(OCC=C)(c1ccccc1)c1ccccc1</smiles>

55<smiles></smiles><smiles>C=CC1=CCOC1(c1ccccc1)c1ccccc1</smiles>

56

solvent: $\mathrm{MeOH} / \mathrm{H}_{2} \mathrm{O} 92 \%$

$\mathrm{EtOH} / \mathrm{H}_{2} \mathrm{O} 99 \%$

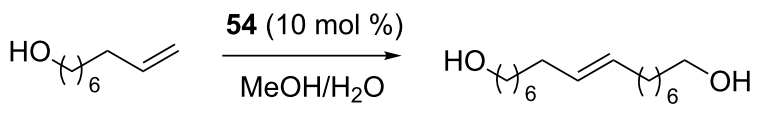

$60,99 \%$ a

solvent: $\mathrm{MeOH} / \mathrm{H}_{2} \mathrm{O} 99 \%$

$\mathrm{EtOH} / \mathrm{H}_{2} \mathrm{O} 83 \%$

Figure 6: Grela's complex (54) and reaction scope in air. Reaction conditions: catalyst, substrate ( 0.25 mmol), nondegassed solvent (5:2; $0.02 \mathrm{M})$,

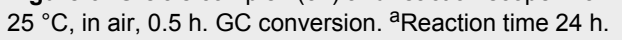

and also increased the activity of the complex due to the electron-withdrawing effects of substituents.

In early 2009, Grubbs and co-workers reported the use of Hoveyda-Grubbs $2^{\text {nd }}$ generation catalyst $33(0.1 \mathrm{~mol} \%)$ in air and in different solvents for the RCM of diethyl diallylmalonate (29) [64]. Conversions were found to be as low as $10 \%$ in DCM and $<20 \%$ in toluene.

In 2009, Abell and Zaman reported the use of a Hoveyda-Grubbs $2^{\text {nd }}$ generation ruthenium-based catalyst immobilized on PEG (61, Figure 7) [65]. This catalyst was soluble in dichloromethane but could be retrieved and recycled by simple exctraction with water or precipitation with ether. With a catalyst loading of $10 \mathrm{~mol} \%$ in refluxing nondegassed dichloromethane, very high conversions were achieved in less than 1 hour for di- and trisubstituted olefins.

Towards the end of 2009, the Meier group reported the use of Grubbs (15), Hoveyda-Grubbs $2^{\text {nd }}$ generation catalyst (33) and a variation of the latter (66, Figure 8) in the RCM of diethyl diallylmalonate (29) [66]. Reactions were performed with very low catalyst loading (from 2.5 to $0.04 \mathrm{~mol} \%$ ), at $30{ }^{\circ} \mathrm{C}$, under air in nondegassed DCM, nondegassed methyl decanoate and

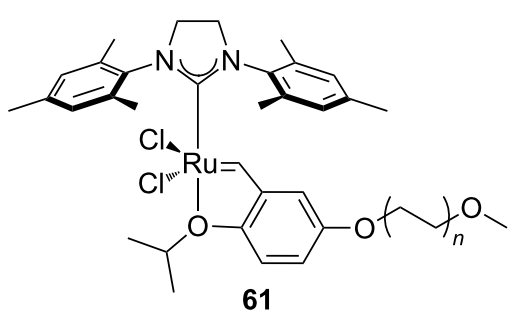<smiles>[AsH3-]N1CC=CC1</smiles>

47

$>98 \%$<smiles>CC1=CCCN([12F])C1</smiles>

63

$95 \%$

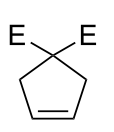

30

$>98 \%$<smiles>[AsH3-]N1CC=CCCC1</smiles>

64

$98 \%$<smiles>[As]N1CC=CCC1</smiles>

62 $>98 \%$

Figure 7: Abell's complex (61) and its RCM reaction scope in air. Reaction condition: $10 \mathrm{~mol} \%$ of 61 , refluxing DCM in air, $0.5 \mathrm{~h}$. Conversion determined by ${ }^{1} \mathrm{H}$ NMR. 


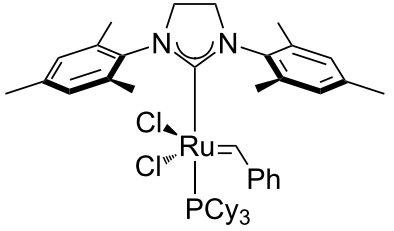

15

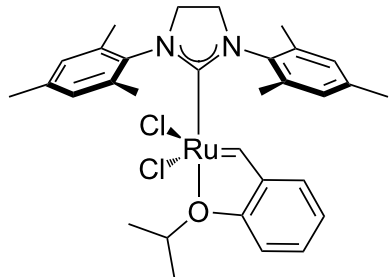

33

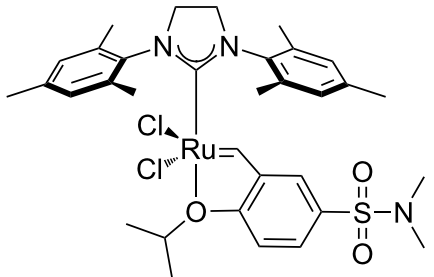

66

Figure 8: Catalysts used by Meier in air.

under solvent-free conditions in nondegassed substrates. Full conversions were achieved in the majority of cases, in both $\mathrm{CM}$ and $\mathrm{RCM}$ reactions, with all catalysts. In these reactions, catalyst 66 gave the highest performance. It should be noted that the results obtained by Meier with $\mathbf{3 3}$ were in contrast with the previous report by Grubbs [64].

In 2012, Grela and co-workers described the synthesis and use of 3 ammonium chloride-tagged variations of
Hoveyda-Grubbs' catalyst (67-69, Figure 9) [67]. The catalysts were active in the isomerization of double bonds, selfmetathesis, RCM and ene-yne metathesis reactions. They afforded average to high yields under air (Table 2). Reactions were performed in water at rt. Catalyst 69 was the most soluble in water; however, it did not afford the highest catalytic activity. In order to test the recyclability of the complex, diethyl diallymalonate (29) was subjected to RCM reaction in refluxing DCM with $1 \mathrm{~mol} \%$ of catalyst $\mathbf{6 9}$. After reaction completion

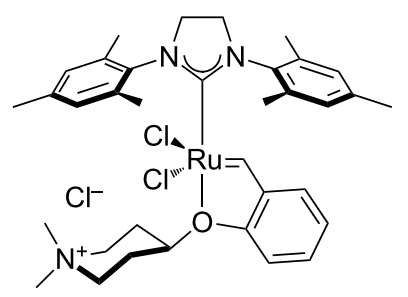

67

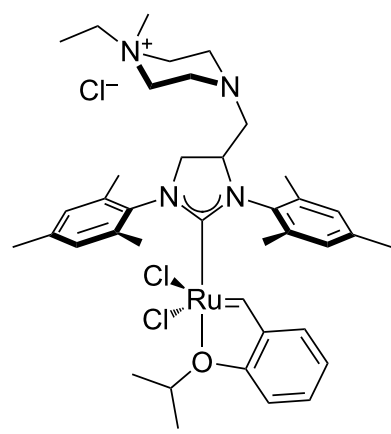

68

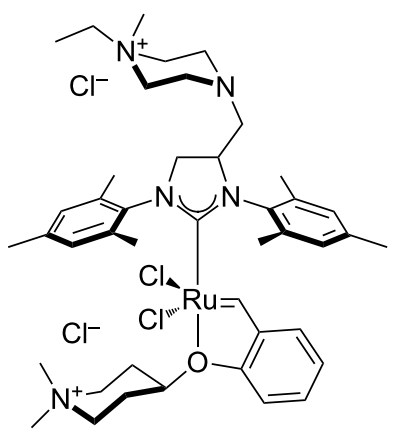

69

Figure 9: Ammonium chloride-tagged complexes.

Table 2: Metathesis reaction in water under air.

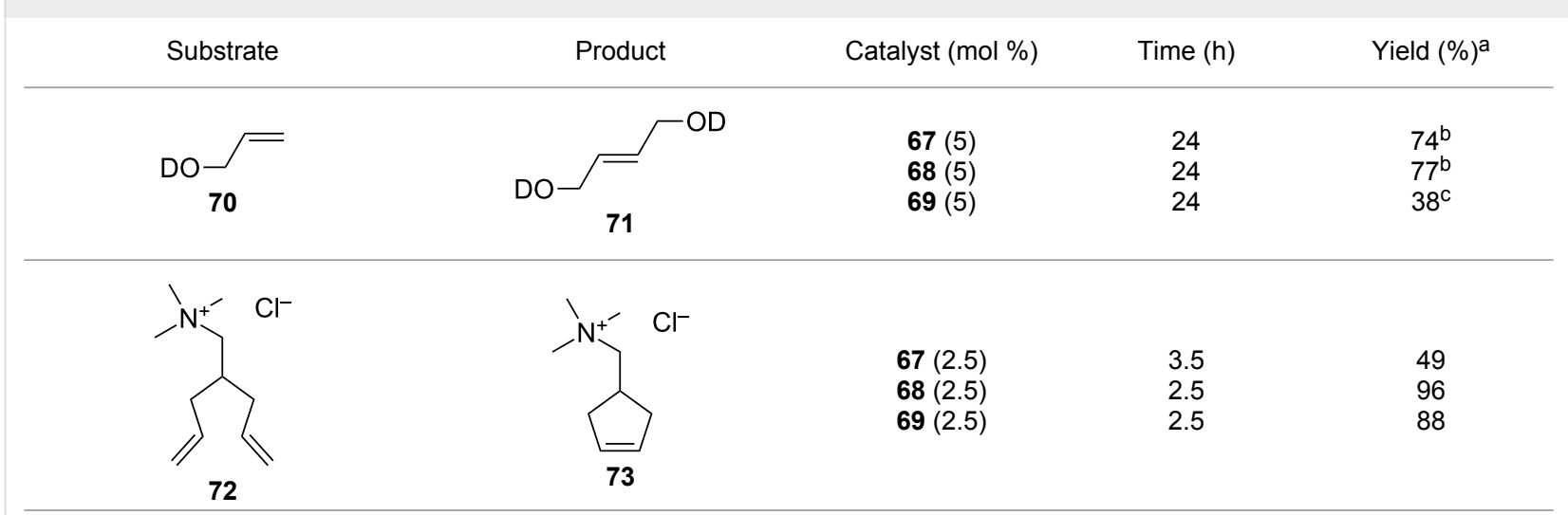

aYields are calculated by NMR spectroscopy. ${ }^{\mathrm{b}} E / Z=16.7: 1 .{ }^{\mathrm{c}} E / Z=12.5: 1$ [67]. 
(97\% isolated yield) and a single extraction with $\mathrm{D}_{2} \mathrm{O},(Z)$-but2-ene-1,4- $\left[{ }^{2} \mathrm{H}\right]$-diol was added to the water phase and isomerization to the trans isomer $\mathbf{7 1}$ was completeted after $1 \mathrm{~h}$, with no decrease in activity ( $94 \%$ isolated yield) observed.

In early 2013, Jensen and co-workers reported a variation of the Hoveyda-Grubbs' $2^{\text {nd }}$ generation catalyst bearing a sulfurbased anion (2,4,6-triphenylbenzenthiolate), replacing one of the chlorides [68]. Despite being a stable and a high $Z$-selective catalyst, it displayed no activity in air, using $0.01 \mathrm{~mol} \%$ catalyst loading.

Later in the same year, Olszewski, Skowerski et al. reported the synthesis and use of new Scorpio-type complexes (Figure 10) [69]. These complexes presented high affinity for silica, which allowed the easy separation and recycling of the catalysts from the reaction mixture. Due to air stability, their activity in nondegassed DCM, toluene and ACS grade ethyl acetate was reported (Table 3). Complex 76b performed slightly better in all cases, regardless of the air atmosphere and of the solvent used. With low catalyst loadings, ranging from 1 to $0.1 \mathrm{~mol} \%$, high to quantitative yields were achieved in all cases.

\section{Grubbs $3^{\text {rd }}$ generation catalyst}

In 2002, Grubbs' and co-workers reported a variation of the $2^{\text {nd }}$ generation catalyst, featuring the substitution of $\mathrm{PCy}_{3}$ with two molecules of 3-bromopyridine (Scheme 8) [70]: Catalyst 81, now known as Grubbs' $3^{\text {rd }}$ generation catalyst, showed the highest rate of initiation reported to date for alkene metathesis reactions.

Complex $\mathbf{8 1}$ is used mostly for ROMP and CM reactions with electron-deficient olefins. The complex can be prepared in air but only one example of its use in air has been reported. In 2010, Tew and co-workers reported the use of $\mathbf{8 1}$ in the living ROMP of a hydrophilic norbornene monomer in air, leading to the formation of hydrogels [71]. Despite the living character of this reaction, the propagating catalyst was found to be inactive after 1 hour.

\section{Indenylidene complexes}

The indenylidene-bearing family of complexes has exhibited a rapid growth in use in recent years and is quickly becoming a mainstream catalyst in metathesis-type reactions (Figure 11). These complexes have received significant attention due to their high activity in olefin metathesis [72-78], their thermal stability and their ease of synthesis $[77,79,80]$.

Complex $\mathbf{8 2}$ is air-stable in the solid state; however, it does not show activity in metathesis-type reactions. On the other hand, its $\mathrm{PCy}_{3}$ counterpart $\mathbf{8 3}$ is as active as the Grubbs' $1^{\text {st }}$ generation catalyst $[73,80,81]$. The NHC-bearing complexes (74, 84-86) showed increased activity and maintained the same thermal stability. Again, these complexes showed similar activity to the Grubbs $2^{\text {nd }}$ generation catalysts $[77,78]$, and are stable when stored under air. Nolan reported the synthesis of Grubbs' $2^{\text {nd }}$ generation catalyst (15) from indenylidene complexes $\mathbf{8 4}$, by simple reaction with styrene, avoiding the use of hazardous diazo compound 7 [82].

Towards the end of 2013, a report by Olszewski, Skowerski and co-workers showed how a variety of commercially available catalysts (Figure 12) could be employed in air with nondegassed ACS grade green solvents. Their results were in line with the ones obtained with DCM and toluene [62]. From Table 4 , it can be seen how ethyl acetate at $70{ }^{\circ} \mathrm{C}$ represented an optimal solvent choice for most of the complexes.

Every catalyst afforded very high yields, in air, with activities comparable to the use of distilled and anhydrous solvents. Also reported was the cyclization of $N$-allyl- $N$-(methallyl)tosylamide (79) in nondegassed and undistilled ethyl acetate (ACS grade), catalyzed by $87(0.25 \mathrm{~mol} \%)$, at $70{ }^{\circ} \mathrm{C}$ in $1 \mathrm{~h}$ with a conversion of $98 \%$.

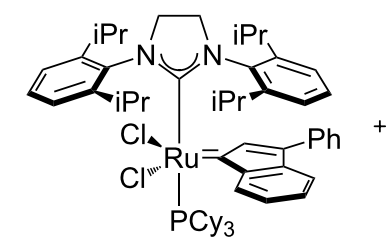

74

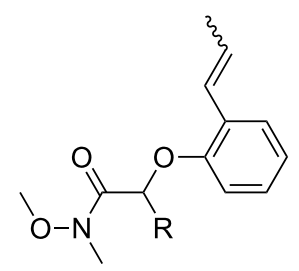

75a,b
a) $R=H$
b) $R=M e$
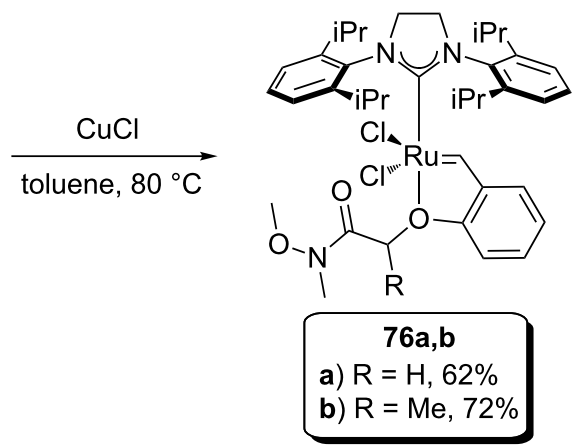

Figure 10: Scorpio-type complexes. 


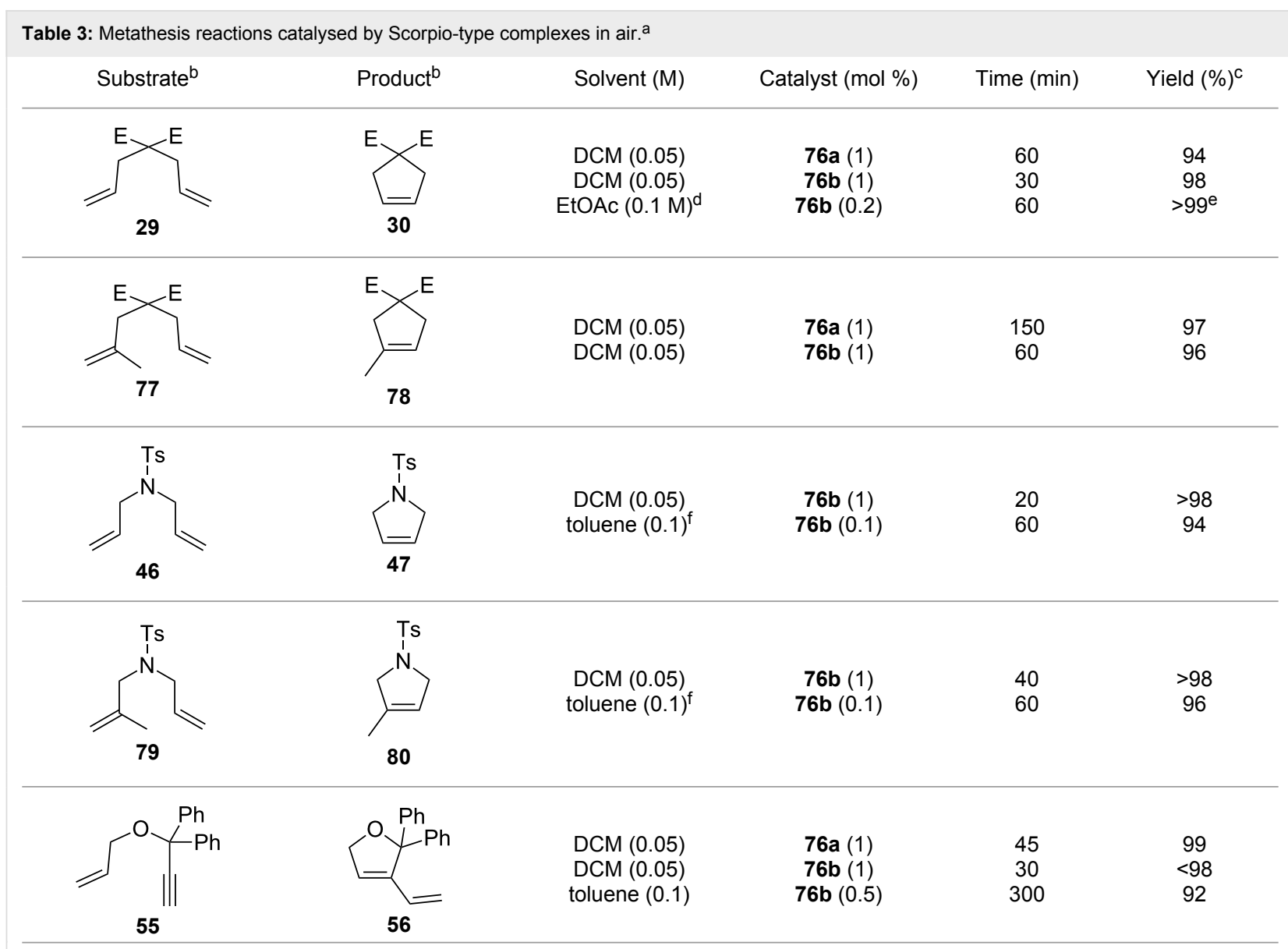

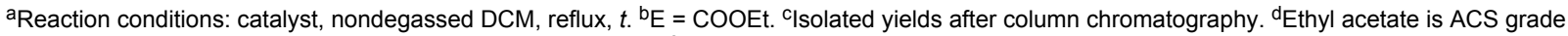
solvent, temperature is $40^{\circ} \mathrm{C}$. ${ }^{e}$ Conversion determined by GC. ${ }^{f}$ Added dropwise with a syringe pump [69].

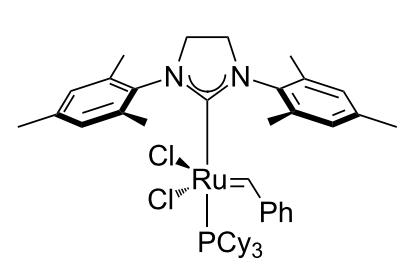

15

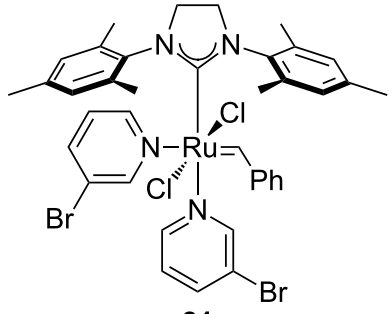

81

Scheme 8: Synthesis of Grubbs' $3^{\text {rd }}$ generation catalyst.

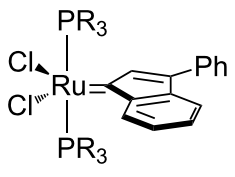

$82 \mathrm{R}=\mathrm{Ph}$

$83 \mathrm{R}=\mathrm{Cy}$

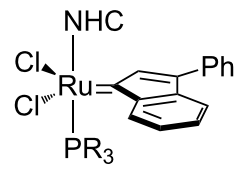

$84 \mathrm{NHC}=$ SIMes; $\mathrm{R}=\mathrm{Ph}$

$85 \mathrm{NHC}=$ SIMes; $\mathrm{R}=\mathrm{Cy}$

$86 \mathrm{NHC}=\mathrm{SIPr} ; \mathrm{R}=\mathrm{Ph}$

$74 \mathrm{NHC}=\mathrm{SIPr} ; \mathrm{R}=\mathrm{Cy}$
Figure 11: Indenylidene complexes

In 2014, Grela and co-workers reported the synthesis $N, N$ unsymmetrically substituted SIMes-bearing indenylidene complexes (93a-f and 94, Figure 13) [83]. They also tested their reactivity under air and in technical grade nondegassed solvents, and compared them to the activity of the commercially available catalyst $\mathbf{8 5}$.

After initial screening and evaluation of their activity with the model substrate, diethyl diallylmalonate (29) (Table 5), 93a, 93b, 93d and 93e were found more active than 85 . When 


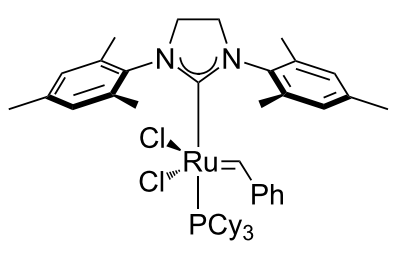

15

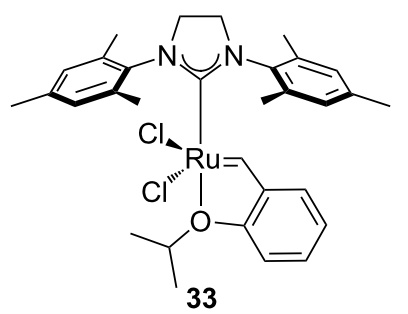

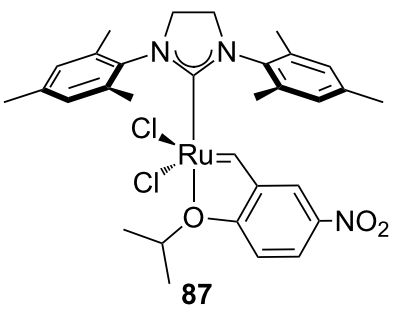<smiles>COC(=O)C(C)Oc1ccccc1CP(Cl)(Cl)(Cl)Oc1ccccc1N1CCN(c2c(C)cc(C)cc2C)C1=O</smiles>

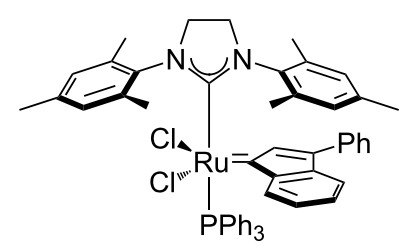

84

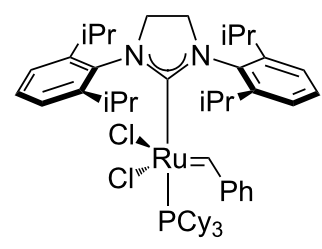

89

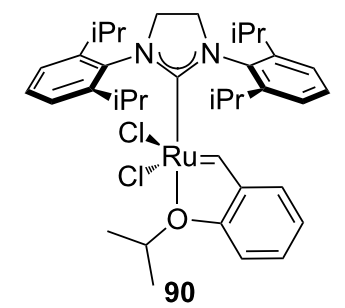

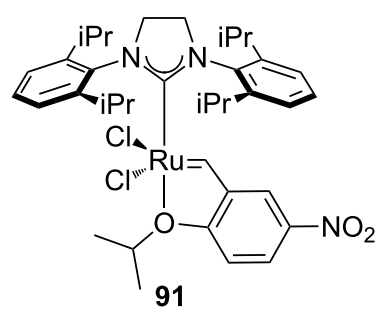

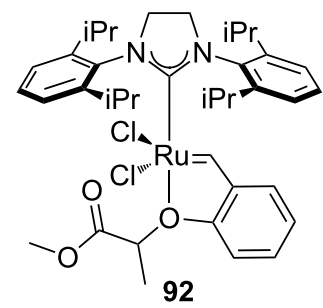

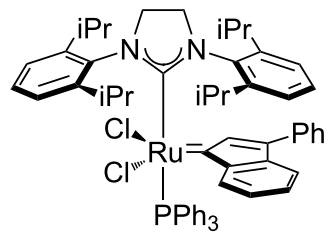

86

Figure 12: Commercially available complexes evaluated under air.

diethyl allyl(methallyl)malonate (77) and $N, N$-bis(methallyl)tosylamide (95) were used, catalysts 93a and 93b performed better than others. A full scope, involving an ene-yne reaction, was carried out with these two complexes in DCM and toluene in comparison with $\mathbf{8 5}$; catalyst loadings were between 1 and $2 \mathrm{~mol} \%$ and reaction times, with the synthesised complexes, were shorter than with $\mathbf{8 5}$.

\section{Phosphite-based catalysts}

In 2010, the Cazin group reported a study on the synthesis and activity of a new family of complexes (98a-d, Scheme 9) [84]; phophite-based complexes were thus synthesized to evaluate possible positive effects of these ligands in alkene metathesis reactions.

Their stability at high temperatures allowed their use in the RCM of bis(methallyl)tosylamide (95) and diethyl bis(methallyl)malonate leading to the highest yields reported to date [85].
In 2015, the same group reported a study on the use of $\mathbf{9 8 a}$ and other commercially available metathesis catalysts $(\mathbf{1 5}, \mathbf{3 3}, \mathbf{8 5}$, Figure 14) [86], under various conditions. Reactions were performed under atmospheres of $\mathrm{N}_{2}, \mathrm{O}_{2}, \mathrm{CO}_{2}$, air, dry air and in the presence of water to evaluate the effect of each on the performance of these catalysts.

A preliminary test on the RCM of bis(methallyl)tosylamide (95), using $0.1 \mathrm{~mol} \%$ of $\mathbf{3 3}, \mathbf{8 5}$ and $98 \mathrm{a}$ under air and in refluxing toluene, showed a $60 \%$ conversion after $20 \mathrm{~min}$ for 98a. Under these conditions, the other catalysts were completely inactive after $20 \mathrm{~min}$ and lead to conversions lower than $40 \%$, when used for prolonged reaction times. After evaluation of the detrimental effects of each of the components of air on catalyst activity, a general trend could be observed: $\mathrm{H}_{2} \mathrm{O}>$ $\mathrm{CO}_{2} \geq \mathrm{O}_{2}$. In all cases, water had the most deleterious effect, whereas reactions could be performed in dry air and in $\mathrm{N}_{2}$ atmosphere without any noticeable differences as compared to their use under inert atmosphere. 
Table 4: RCM with commercially available catalysts in technical grade solvents. ${ }^{\text {a }}$

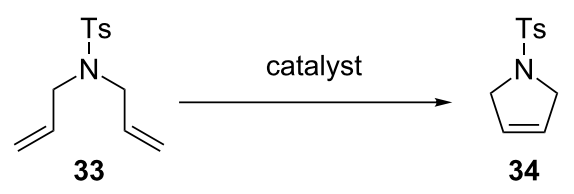

\begin{tabular}{|c|c|c|c|c|c|c|}
\hline \multirow[b]{2}{*}{ Catalyst } & \multirow[b]{2}{*}{$T\left({ }^{\circ} \mathrm{C}\right)$} & \multicolumn{5}{|c|}{ GC yield (\%) } \\
\hline & & AcOEt & DMC & CPME & 2-MeTHF & DCM/toluene ${ }^{b}$ \\
\hline \multirow[t]{2}{*}{15} & 40 & 97 & 98 & 80 & 35 & 92 \\
\hline & 70 & 98 & 98 & 97 & 95 & 67 \\
\hline \multirow[t]{2}{*}{87} & 40 & 94 & 85 & 79 & 49 & 96 \\
\hline & 70 & 98 & 98 & 97 & 65 & 65 \\
\hline \multirow[t]{2}{*}{88} & 40 & 66 & 79 & 20 & 37 & 98 \\
\hline & 70 & 99 & 98 & 60 & 65 & 61 \\
\hline \multirow[t]{2}{*}{84} & 40 & 96 & 98 & 69 & 38 & 93 \\
\hline & 70 & 98 & 98 & 95 & 92 & 59 \\
\hline \multirow[t]{2}{*}{89} & 40 & 88 & 98 & 85 & 84 & 91 \\
\hline & 70 & 99 & 98 & 92 & 97 & 98 \\
\hline \multirow[t]{2}{*}{91} & 40 & 96 & 99 & 97 & 97 & 88 \\
\hline & 70 & 99 & 99 & 99 & 99 & 99 \\
\hline \multirow[t]{2}{*}{92} & 40 & 98 & 99 & 97 & 97 & 91 \\
\hline & 70 & 99 & 99 & 99 & 98 & 99 \\
\hline \multirow[t]{2}{*}{86} & 40 & 92 & 98 & 89 & 93 & 95 \\
\hline & 70 & 94 & 98 & 84 & 98 & 96 \\
\hline
\end{tabular}

aReaction conditions: Cat. 0.25 mol \%, nondegassed, undistilled ACS grade solvents in air (0.1 M), 1 h. DMC: dimethyl carbonate; CPME: cyclopentyl methyl ether; 2-MeTHF: 2-methyltetrahydrofuran. ${ }^{\mathrm{b}} \mathrm{DCM}$ was used at $40^{\circ} \mathrm{C}$ while toluene at $70{ }^{\circ} \mathrm{C}$ [62].
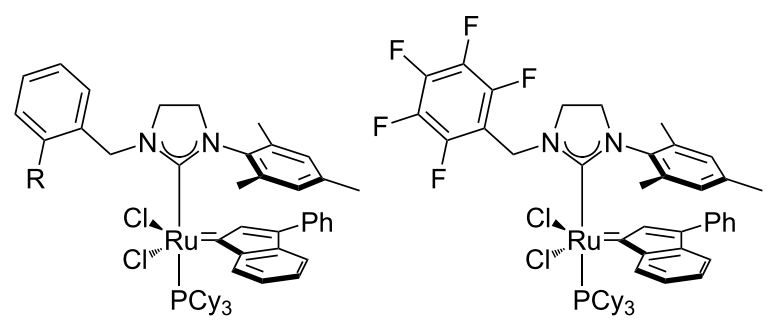

93a-f

a) $\mathrm{R}=\mathrm{OMe}$

b) $\mathrm{R}=\mathrm{NMe}$

c) $\mathrm{R}=\mathrm{SMe}$

d) $\mathrm{R}=\mathrm{H}$

e) $R=I$

f) $\mathrm{R}=\mathrm{iPr}$

Figure 13: Grela's N,N-unsymmetrically substituted complexes.

Catalyst 98a, with concentrations ranging from 0.05 to $0.5 \mathrm{~mol} \%$, exhibited the most remarkable activity in air with high to quantitative yields in the RCM, CM and ene-yne reactions. Furthermore, complexes $\mathbf{3 3}$ and $\mathbf{8 5}$ were able to perform the RCM reactions under the same conditions, with yields ranging from moderate to excellent (Figure 15).

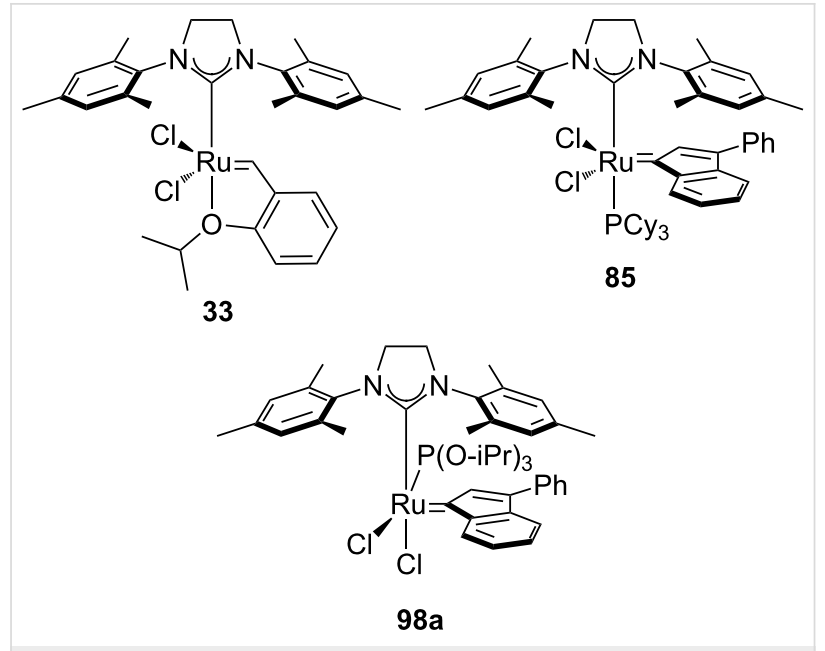

Figure 14: Catalysts used by the Cazin group.

\section{Schiff bases}

Schiff bases in metathesis are usually O,N-bidentate ligands and represent an interesting alternative family of ligands as $[18,87-$ 94]: 1) they can be produced in one high yielding step by condensation of an aldehyde and an amine, thus allowing the fine and facile tuning of ligand and catalyst steric and electronic 


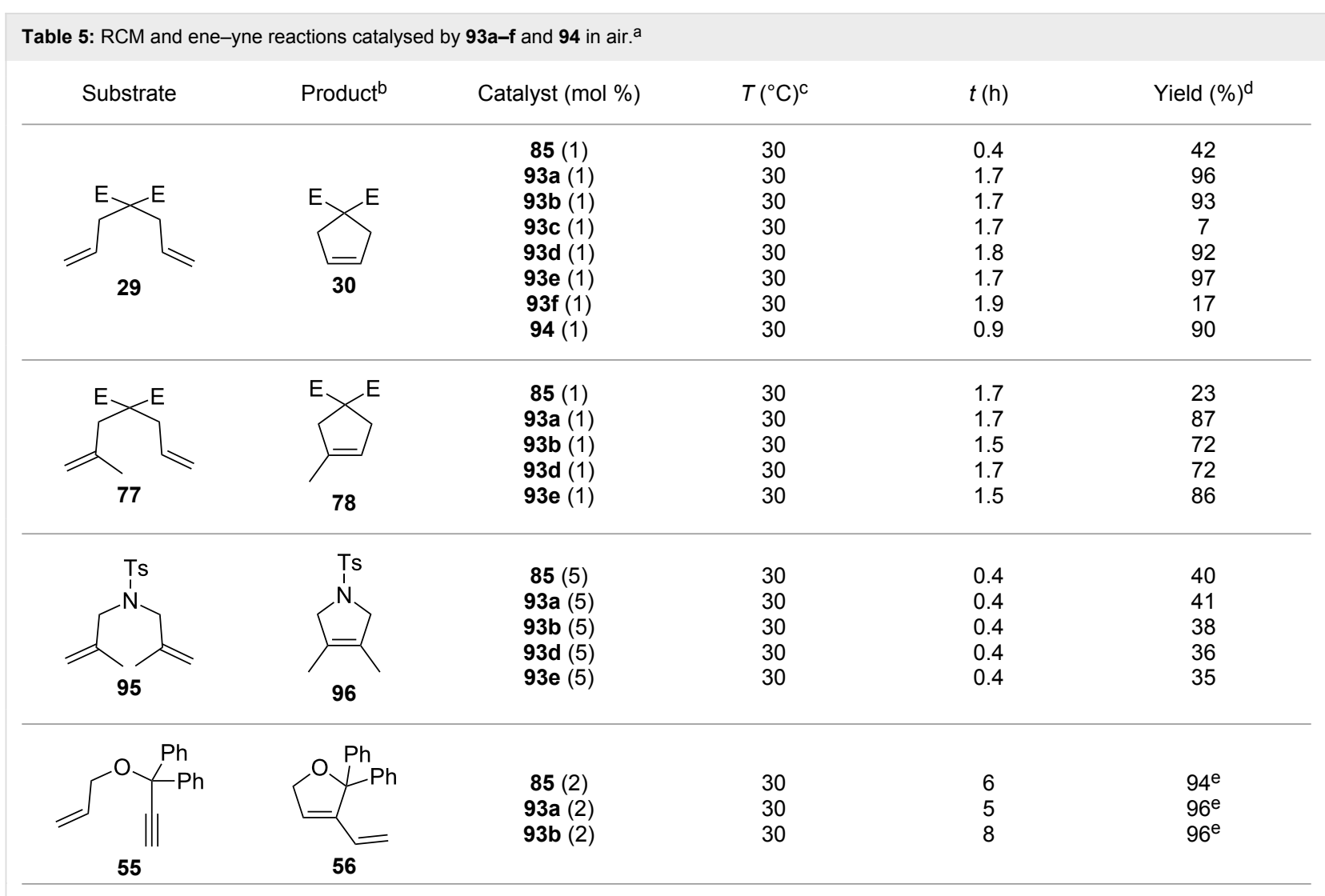

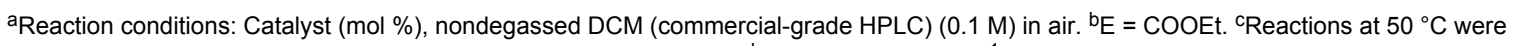
performed in nondegassed toluene (commercial-grade HPLC) in air. ${ }^{d}$ Yields determined by ${ }^{1} \mathrm{H}$ NMR. ${ }^{\mathrm{e}}$ Isolated yields after flash chromatography [83].

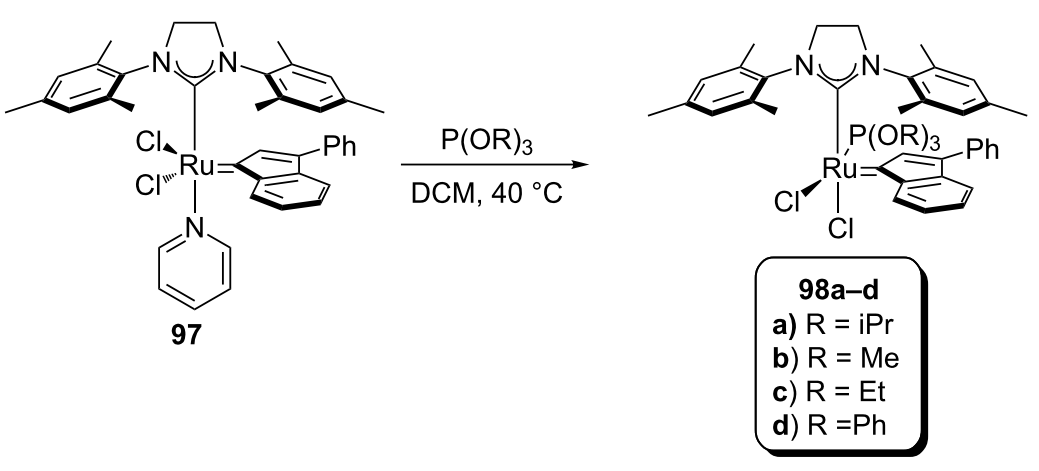

Scheme 9: Synthesis of phosphite-based catalysts.

properties; and 2) the two different donor atoms, $\mathrm{O}$ (hard) and $\mathrm{N}$ (soft), offer different features and therefore can stabilize, respectively, high and low oxidation states.

Ruthenium carbene complexes bearing Schiff bases were synthesized originally by the Grubbs' group and applied in RCM reactions [95], showing lower activity then the Grubbs $1^{\text {st }}$ generation catalyst but exhibited very high termal stability (Figure 16).
In 2002 and 2003, the Verpoort group synthesized and applied a variety of Schiff base adapted complexes in RCM [87] and ROMP $[87,93,94,96,97]$ reactions (Scheme 10). This class of complexes showed high activity and very high stability to air and water, compared to Grubbs $1^{\text {st }}$ and $2^{\text {nd }}$ generation catalysts [7]. RCM reactions were performed in air with $5 \mathrm{~mol} \%$ of the catalyst, showing high yields for terminal dienes (Table 6, entry 1). In the absence of SIMes, increasing the olefin substitution led to low yields in all catalytic systems. An electron-with- 
<smiles>[3H]N1CC(C)=C(C)C1</smiles>

96<smiles>CC1=C(C)CC(F)(F)C1</smiles>

99<smiles>C#CC(C)(OCC=C)c1ccccc1</smiles>

100<smiles>C=CC1=CCOC1(C)c1ccccc1</smiles>

101 98a (0.1 mol \%): 99(99)

$33(0.1 \mathrm{~mol} \%): 93$

85 (0.1 mol \%): 91 98a (0.5 mol \%): 81(80)

$33(0.5 \mathrm{~mol} \%): 21$

85 (0.5 mol \%): 52<smiles>C=CCCOC(=O)c1ccccc1</smiles><smiles>C=CC(=O)OC</smiles><smiles>[13CH2]I</smiles>

103

98a $(0.5 \mathrm{~mol} \%): 81(80)^{\mathrm{b}}$

(5 equiv)

98a (0.5 mol \%): 75(72), [>20:1 $]^{\mathrm{b}, \mathrm{c}}$

Figure 15: RCM scope in air with catalysts 33,85 and $98 \mathrm{a}$. Reaction conditions: Catalyst, substrate $(0.25 \mathrm{mmol})$, reagent-grade toluene $(0.5 \mathrm{~mL})$,

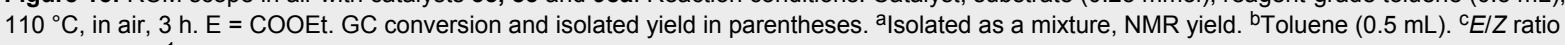
determined by ${ }^{1} \mathrm{H}$ NMR<smiles>[R]N=Cc1ccc(C)c(O)c1[R]</smiles>

9

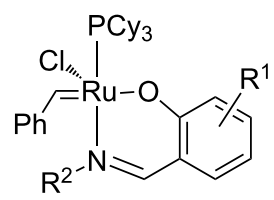

$\mathrm{R}^{1}=\mathrm{H} ; \mathrm{NO}_{2} ; 6-\mathrm{Me}-4-\mathrm{NO}_{2}$

$\mathrm{R}^{2}=2,6-\mathrm{iPrC}_{6} \mathrm{H}_{3} ; 2,6-\mathrm{Me}-4-\mathrm{MeOC}_{6} \mathrm{H}_{2}$; $2,6-\mathrm{Me}-4-\mathrm{BrC}_{6} \mathrm{H}_{2} ; 2,6-\mathrm{Cl}-4-\mathrm{FC}_{6} \mathrm{H}_{2}$; 2,6-iPr-4-NO ${ }_{2}-\mathrm{C}_{6} \mathrm{H}_{3} ; 2$-adamantyl

Figure 16: Synthesis of Schiff base-ruthenium complexes.

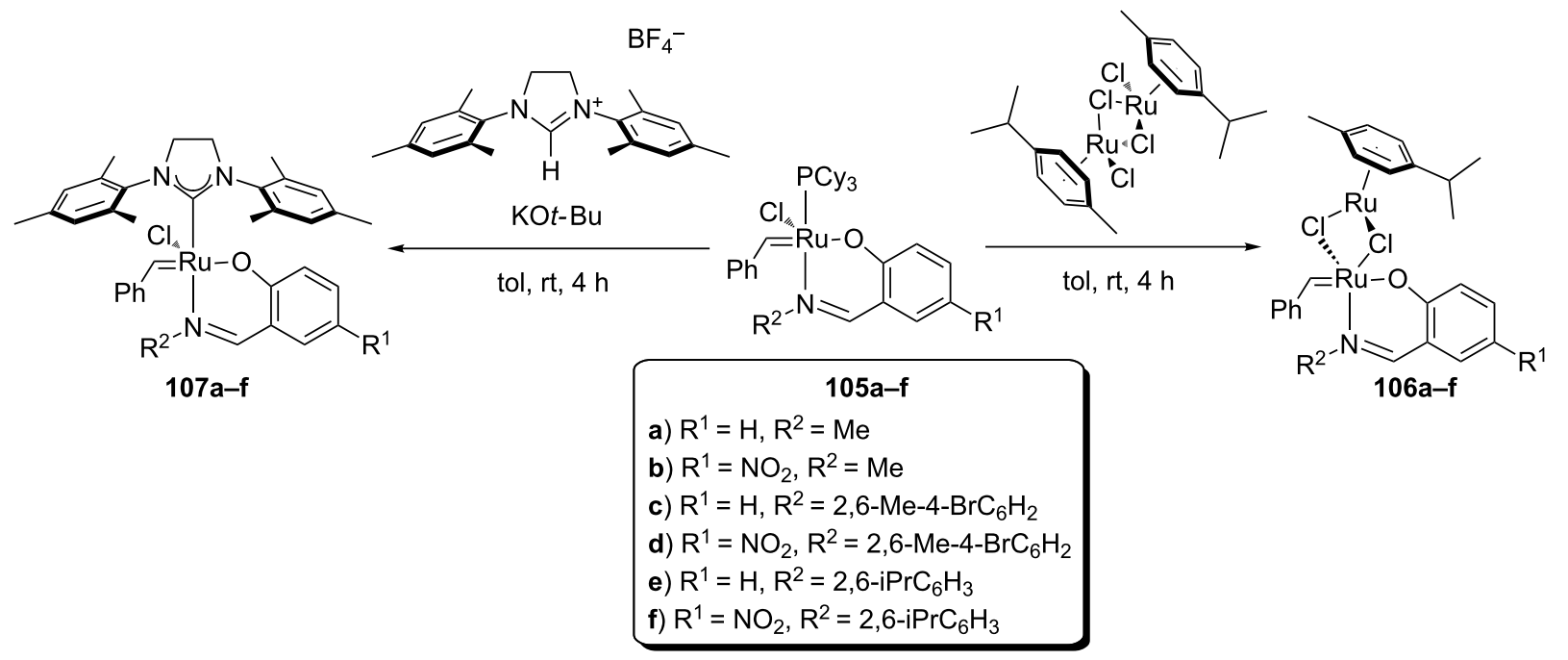

Scheme 10: Schiff base-ruthenium complexes synthesized by Verpoort. 
drawing substituent on the phenyl ring and a bulky group on the imine generally lead to higher activity for both mono- and bimetallic systems. SIMes-bearing complexes are more active than monometallic systems in all cases, and more active than bimetallic systems only when the iminic substituent is less bulky (Table 6, entries 2 and 3).

In 2007, Raines et al. reported that $\mathbf{1 0 8 b}$ (Scheme 11) remained intact after 8 days in $\mathrm{C}_{6} \mathrm{D}_{6}$ under air [7]. This prompted them to explore the activity of mixed Schiff-NHC complexes in RCM and ene-yne reactions using protic solvents in air.

As can be seen from Table 7, catalyst $108 \mathrm{c}$, bearing a watersoluble tag, is active in $\mathrm{D}_{2} \mathrm{O}$ and in water/methanol mixtures under air and the presence of the tag does not influence the re- activity. Although high conversions were obtained, high catalyst loadings (5-10 mol \%) of all catalysts were required.

In 2009, surely inspired by the aforementioned work, the Verpoort group reported a family of indenylidene Schiff base-ruthenium complexes (111a-f, Figure 17) for CM and RCM reactions in air [98]. They combined the higher thermal stability of indenylidene complexes and the tunability and stability of Schiff base ligands. These complexes were able to perform CM and RCM reactions in air with lower catayst loadings compared to 105a-f, 106a-f, 107a-f and 111a-c. RCM reactions proceeded smoothly using $N, N$-diallyltosylamide (46) giving, with all catalysts, quantitative yields. When a more challenging substrate ( $N$-allyl- $N$-(methallyl)tosylamide, 79) was used, a $24 \mathrm{~h}$ reaction time was needed in all cases, with the

Table 6: Yield (\%) of RCM reactions using catalysts $105 a-f, 106 a-f$ and $107 a-f$ in air. ${ }^{a}$

Entry Product ${ }^{b} \quad$ Yield (\%)

105a/106a/107a 105b/106b/107b 105c/106c/107c 105d/106d/107d $105 e / 106 e / 107 e \quad 105 f / 106 f / 107 f$<smiles>FC1(F)CC=CC1</smiles>

$100 / 100 / 100$

30

2<smiles>CC1=CCC(F)(F)C1</smiles>

$<5 / 13 / 72$

77

3<smiles>CC1=C(C)CC(F)(F)C1</smiles>

$100 / 100 / 100$

$100 / 100 / 100$

$100 / 100 / 100$

$100 / 100 / 100$

$100 / 100 / 100$

99

${ }^{a}$ Reaction conditions: catalyst $(5 \mathrm{~mol} \%)$, distilled $\mathrm{C}_{6} \mathrm{D}_{5} \mathrm{Cl}(0.05 \mathrm{M}), 55^{\circ} \mathrm{C}$, in air for catalysts $105 \mathrm{a}-\mathrm{f}$ and $70{ }^{\circ} \mathrm{C}$ for catalysts $106 \mathrm{a}-\mathrm{f}, 4 \mathrm{~h}[96]$. For catalysts $107 \mathrm{a}-\mathrm{f}$ undistilled $\mathrm{C}_{6} \mathrm{D}_{6}$ was used as solvent and temperature was $55^{\circ} \mathrm{C}, 4 \mathrm{~h}$, in air [97]. ${ }^{\mathrm{b}} \mathrm{E}=\mathrm{COOEt}$.<smiles>[R]c1ccc(O)c(/C=N/c2c(C)cc(Br)cc2C)c1</smiles>

$106 a-c$

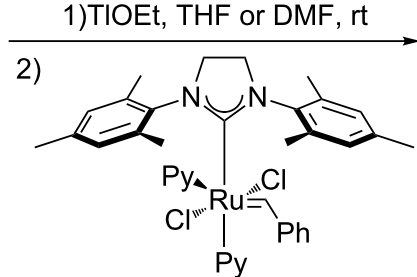

107

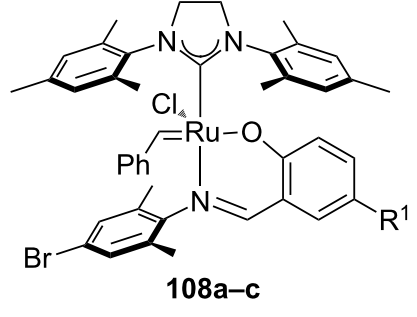

a) $\mathrm{R}=\mathrm{H}$

b) $\mathrm{R}=\mathrm{NO}_{2}$

c) $\mathrm{R}=\mathrm{NMe}_{3}{ }^{+} \mathrm{Cl}^{-}$ 


\begin{tabular}{|c|c|c|c|c|c|}
\hline Substrate $^{b}$ & Product $^{b}$ & Solvent (substrate conc. [M]) & Complex (mol \%) & Time $[\mathrm{h}]$ & Conversion $[\%]^{\mathrm{C}}$ \\
\hline 29 & 30 & $\begin{array}{c}\mathrm{C}_{6} \mathrm{D}_{6}(0.1) \\
\mathrm{C}_{7} \mathrm{D}_{8}(0.05) \\
\mathrm{CD}_{3} \mathrm{OD}(0.025) \\
\mathrm{C}_{6} \mathrm{D}_{6}(0.05)\end{array}$ & $\begin{array}{l}108 \mathrm{a}(5) \\
108 \mathrm{~b}(5) \\
108 b(5) \\
108 c(5)\end{array}$ & $\begin{array}{l}72 \\
70 \\
23 \\
40\end{array}$ & $\begin{array}{c}90 \\
79 \\
94 \\
>95\end{array}$ \\
\hline 46 & 47 & $\begin{array}{c}\mathrm{C}_{6} \mathrm{D}_{6}(0.05) \\
\mathrm{C}_{7} \mathrm{D}_{8}(0.05) \\
\mathrm{CD}_{3} \mathrm{OD}(0.025) \\
\mathrm{CD}_{3} \mathrm{OD}(0.05) \\
2: 1 \mathrm{CD}_{3} \mathrm{OD} / \mathrm{D}_{2} \mathrm{O}(0.025)\end{array}$ & $\begin{array}{l}108 a(5) \\
108 b(5) \\
108 b(5) \\
108 c(5) \\
108 c(5)\end{array}$ & $\begin{array}{c}26 \\
70 \\
9 \\
6 \\
6\end{array}$ & $\begin{array}{c}68 \\
92 \\
>95 \\
>95 \\
93\end{array}$ \\
\hline 109 & 110 & $\begin{array}{c}\mathrm{CD}_{3} \mathrm{OD}(0.05) \\
2: 1 \mathrm{CD}_{3} \mathrm{OD} / \mathrm{D}_{2} \mathrm{O}(0.025)\end{array}$ & $\begin{array}{c}108 c(5) \\
108 c(10)\end{array}$ & $\begin{array}{c}12 \\
6\end{array}$ & $\begin{array}{l}79 \\
40\end{array}$ \\
\hline 55 & 56 & $\begin{array}{c}\mathrm{C}_{7} \mathrm{D}_{8}(0.05) \\
\mathrm{C}_{7} \mathrm{D}_{8}(0.05) \\
\mathrm{CD}_{3} \mathrm{OD}(0.025) \\
\mathrm{C}_{6} \mathrm{D}_{6}(0.05) \\
\mathrm{CD}_{3} \mathrm{OD}(0.05)\end{array}$ & $\begin{array}{l}108 \mathrm{a}(5) \\
108 \mathrm{~b}(5) \\
108 \mathrm{~b}(5) \\
108 \mathrm{c}(5) \\
108 \mathrm{c}(5)\end{array}$ & $\begin{array}{c}36 \\
18 \\
2 \\
5 \\
2\end{array}$ & $\begin{array}{c}93 \\
>95 \\
90 \\
>95 \\
>95\end{array}$ \\
\hline
\end{tabular}

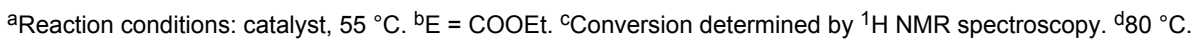

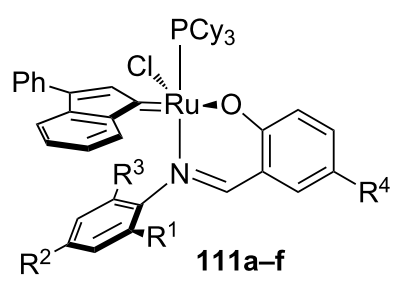

a) $\mathrm{R}^{1}=\mathrm{CH}_{3}, \mathrm{R}^{2}=\mathrm{H}, \mathrm{R}^{3}=\mathrm{H}, \mathrm{R}^{4}=\mathrm{H}$

b) $\mathrm{R}^{1}=\mathrm{CH}_{3}, \mathrm{R}^{2}=\mathrm{CH}_{3}, \mathrm{R}^{3}=\mathrm{CH}_{3}, \mathrm{R}^{4}=\mathrm{H}$

c) $\mathrm{R}^{1}=\mathrm{CH}_{3}, \mathrm{R}^{2}=\mathrm{H}, \mathrm{R}^{3}=\mathrm{CH}_{3}, \mathrm{R}^{4}=\mathrm{NO}_{2}$

d) $\mathrm{R}^{1}=\mathrm{Cl}, \mathrm{R}^{2}=\mathrm{H}, \mathrm{R}^{3}=\mathrm{H}, \mathrm{R}^{4}=\mathrm{NO}_{2}$

e) $\mathrm{R}^{1}=\mathrm{CH}_{3}, \mathrm{R}^{2}=\mathrm{CH}_{3}, \mathrm{R}^{3}=\mathrm{CH}_{3}, \mathrm{R}^{4}=\mathrm{NO}_{2}$

f) $\mathrm{R}^{1}=\mathrm{iPr}, \mathrm{R}^{2}=\mathrm{H}, \mathrm{R}^{3}=\mathrm{iPr}, \mathrm{R}^{4}=\mathrm{NO}_{2}$

Figure 17: Veerport's indenylidene Schiff-base complexes.

exception of 111d (Table 8). This remarkable activity (higher than Hoveyda-Grubbs $2^{\text {nd }}$ generation catalyst, 33) was due to the presence of the electron-withdrawing substituents on the Schiff base.

\section{Conclusion}

Although metathesis-type reactions represent one of the most valuable strategies in modern organic synthesis, making this highly valuable tool more accessible and practical for routine use still remains a challenge. Ruthenium-based catalysts have been at the centre of recent advancements making possible their

\begin{tabular}{|c|c|c|c|}
\hline $\begin{array}{c}\text { Ts } \\
\vdots \\
N\end{array}$ & & & \\
\hline \multirow[t]{2}{*}{ Catalyst (0.5 mol \%) } & \multicolumn{3}{|c|}{ Yield over time } \\
\hline & $1 \mathrm{~h}$ & $3 \mathrm{~h}$ & $24 \mathrm{~h}$ \\
\hline $111 a$ & 18 & 37 & 51 \\
\hline 111b & 45 & 67 & 97 \\
\hline $111 \mathrm{c}$ & 14 & 37 & 87 \\
\hline $111 d$ & 87 & 100 & 100 \\
\hline $111 \mathrm{e}$ & 36 & 68 & 97 \\
\hline $111 f$ & 28 & 55 & 100 \\
\hline
\end{tabular}

aReaction conditions: catalyst, $\mathrm{CH}_{3} \mathrm{Cl}(0.1 \mathrm{M}), 60^{\circ} \mathrm{C}$ in air.

use in air, moreover these catalysts are becoming more and more stable, efficient and economically friendly with time. With the current development directed towards air and moisture stability and high performance, there is no doubt that more reports will push these reactivity/tolerance limits even further. As seen in this review, conducting metathesis-type reactions in air, in the presence of water and under high temperature has become more concrete, with several groups leading the charge $[62,86]$. 


\section{References}

1. Hoveyda, A. H.; Zhugralin, A. R. Nature 2007, 450, 243-251. doi:10.1038/nature06351

2. Malcolmson, S. J.; Meek, S. J.; Sattely, E. S.; Schrock, R. R.; Hoveyda, A. H. Nature 2008, 456, 933-937. doi:10.1038/nature07594

3. Fürstner, A. Angew. Chem., Int. Ed. 2000, 39, 3012-3043. doi:10.1002/1521-3773(20000901)39:17<3012::AID-ANIE3012>3.0.CO ;2-G

4. Diesendruck, C. E.; Tzur, E.; Lemcoff, N. G. Eur. J. Inorg. Chem. 2009, 2009, 4185-4203. doi:10.1002/ejic.200900526

5. Trnka, T. M.; Grubbs, R. H. Acc. Chem. Res. 2001, 34, 18-29. doi:10.1021/ar000114f

6. Bieniek, M.; Michrowska, A.; Usanov, D. L.; Grela, K. Chem. - Eur. J. 2008, 14, 806-818. doi:10.1002/chem.200701340

7. Binder, J. B.; Guzei, I. A.; Raines, R. T. Adv. Synth. Catal. 2007, 349, 395-404. doi:10.1002/adsc.200600264

8. Lozano-Vila, A. M.; Monsaert, S.; Bajek, A.; Verpoort, F. Chem. Rev. 2010, 110, 4865-4909. doi:10.1021/cr900346r

9. Astruc, D. New J. Chem. 2005, 29, 42-56. doi:10.1039/b412198h

10. Grela, K., Ed. Olefin Metatehsis: Theory and Practice; John Wiley \& Sons, Inc.: Hoboken, NJ, U.S.A., 2014. doi:10.1002/9781118711613

11. Leitgeb, A.; Wappel, J.; Slugovc, C. Polymer 2010, 51, 2927-2946. doi:10.1016/j.polymer.2010.05.002

12. Bielawski, C. W.; Grubbs, R. H. Prog. Polym. Sci. 2007, 32, 1-29. doi:10.1016/j.progpolymsci.2006.08.006

13. Grubbs, R. H., Ed. Handbook of Metathesis; Wiley-VCH: New York, NY, U.S.A., 2003. doi:10.1002/9783527619481

14. Mol, J. C. J. Mol. Catal. A: Chem. 2004, 213, 39-45. doi:10.1016/j.molcata.2003.10.049

15. Baughman, T. W.; Wagener, K. B. Adv. Polym. Sci. 2005, 176, 1-42. doi:10.1007/b101318

16. Buchmeiser, M. R. Chem. Rev. 2000, 100, 1565-1604. doi:10.1021/cr990248a

17. Lynn, D. M.; Mohr, B.; Grubbs, R. H. J. Am. Chem. Soc. 1998, 120, 1627-1628. doi:10.1021/ja9736323

18. Drozdzak, R.; Allaert, B.; Ledoux, N.; Dragutan, I.; Dragutan, V.; Verpoort, F. Coord. Chem. Rev. 2005, 249, 3055-3074. doi:10.1016/j.ccr.2005.05.003

19. Reymond, S.; Ferrié, L.; Guérinot, A.; Capdevielle, P.; Cossy, J. Pure Appl. Chem. 2008, 80, 1683-1691. doi:10.1351/pac200880081683

20. Hoveyda, A. H.; Malcolmson, S. J.; Meek, S. J.; Zhugralin, A. R. Angew. Chem., Int. Ed. 2010, 49, 34-44. doi:10.1002/anie.200904491

21. Nicolaou, K. C.; Bulger, P. G.; Sarlah, D. Angew. Chem., Int. Ed. 2005, 44, 4490-4527. doi:10.1002/anie.200500369

22. Connon, S. J.; Blechert, S. Angew. Chem., Int. Ed. 2003, 42, 1900-1923. doi:10.1002/anie.200200556

23. Požgan, F.; Dixneuf, P. H. Recent Applications Of Alkene Metathesis For Fine Chemical And Supramolecular System Synthesis. In Metathesis Chemistry; Imamoglu, Y.; Dragutan, V.; Karabulut, S., Eds.; NATO Science Series, Vol. 243; Springer: Berlin, Germany, 2007; pp 195-222. doi:10.1007/978-1-4020-6091-5_12

24. Mele, G. L. J.; Vasapollo, G. Chim. Oggi 2008, 26, 72-74.

25. Olszewski, T. K.; Figlus, M.; Bienek, M. Chim. Oggi 2014, 32, 22-29.

26. The Nobel Prize in Chemistry 2005.

http://www.nobelprize.org/nobel_prizes/chemistry/laureates/2005/ (accessed July 13, 2015).

27. Schuster, M.; Blechert, S. Angew. Chem., Int. Ed. Engl. 1997, 36 2036-2056. doi:10.1002/anie.199720361
28. Deshmukh, P. H.; Blechert, S. Dalton Trans. 2007, 2479-2491. doi:10.1039/b703164p

29. Grubbs, R. H. Tetrahedron 2004, 60, 7117-7140. doi:10.1016/j.tet.2004.05.124

30. Schrock, R. R.; Czekelius, C. Adv. Synth. Catal. 2007, 349, 55-77. doi:10.1002/adsc.200600459

31. Novak, B. M.; Grubbs, R. H. J. Am. Chem. Soc. 1988, 110, 7542-7543. doi:10.1021/ja00230a047

32. Novak, B. M.; Grubbs, R. H. J. Am. Chem. Soc. 1988, 110, 960-961. doi:10.1021/ja00211a043

33. Marciniec, B.; Pietraszuk, C. J. Organomet. Chem. 1991, 412, C1-C3. doi:10.1016/0022-328X(91)86064-W

34. France, M. B.; Grubbs, R. H.; Mcgrath, D. V.; Paciello, R. A. Macromolecules 1993, 26, 4742-4747. doi:10.1021/ma00070a002

35. Nguyen, S. T.; Johnson, L. K.; Grubbs, R. H.; Ziller, J. W. J. Am. Chem. Soc. 1992, 114, 3974-3975. doi:10.1021/ja00036a053

36. Schwab, P.; France, M. B.; Ziller, J. W.; Grubbs, R. H. Angew. Chem., Int. Ed. Engl. 1995, 34, 2039-2041. doi:10.1002/anie.199520391

37. Nguyen, S. T.; Grubbs, R. H.; Ziller, J. W. J. Am. Chem. Soc. 1993, 115, 9858-9859. doi:10.1021/ja00074a086

38. Schwab, P.; Grubbs, R. H.; Ziller, J. W. J. Am. Chem. Soc. 1996, 118, 100-110. doi:10.1021/ja952676d

39. Weskamp, T.; Schattenmann, W. C.; Spiegler, M.; Herrmann, W. A. Angew. Chem., Int. Ed. 1998, 37, 2490-2493. doi:10.1002/(SICI)1521-3773(19981002)37:18<2490::AID-ANIE2490>3 .0.CO;2-X

40. Huang, J.; Schanz, H.-J.; Stevens, E. D.; Nolan, S. P. Organometallics 1999, 18, 5375-5380. doi:10.1021/om990788y

41. Huang, J.; Stevens, E. D.; Nolan, S. P.; Petersen, J. L. J. Am. Chem. Soc. 1999, 121, 2674-2678. doi:10.1021/ja9831352

42. Scholl, M.; Trnka, T. M.; Morgan, J. P.; Grubbs, R. H. Tetrahedron Lett. 1999, 40, 2247-2250. doi:10.1016/S0040-4039(99)00217-8

43. Scholl, M.; Ding, S.; Lee, C. W.; Grubbs, R. H. Org. Lett. 1999, 1 , 953-956. doi:10.1021/ol990909q

44. Chatterjee, A. K.; Grubbs, R. H. Org. Lett. 1999, 1, 1751-1753. doi:10.1021/ol991023p

45. Chatterjee, A. K.; Morgan, J. P.; Scholl, M.; Grubbs, R. H. J. Am. Chem. Soc. 2000, 122, 3783-3784. doi:10.1021/ja9939744

46. Ackermann, L.; Fürstner, A.; Weskamp, T.; Kohl, F. J.; Herrmann, W. A. Tetrahedron Lett. 1999, 40, 4787-4790. doi:10.1016/S0040-4039(99)00919-3

47. Weskamp, T.; Kohl, F. J.; Hieringer, W.; Gleich, D.; Herrmann, W. A Angew. Chem., Int. Ed. 1999, 38, 2416-2419. doi:10.1002/(SICI)1521-3773(19990816)38:16<2416::AID-ANIE2416>3 .0.CO;2-\#

48. Weskamp, T.; Kohl, F. J.; Herrmann, W. A. J. Organomet. Chem. 1999, 582, 362-365. doi:10.1016/S0022-328X(99)00163-1

49. Samojłowicz, C.; Bieniek, M.; Grela, K. Chem. Rev. 2009, 109, 3708-3742. doi:10.1021/cr800524f

50. Ulman, M.; Grubbs, R. H. J. Org. Chem. 1999, 64, 7202-7207. doi:10.1021/jo9908703

51. Kingsbury, J. S.; Harrity, J. P. A.; Bonitatebus, P. J., Jr.; Hoveyda, A. H. J. Am. Chem. Soc. 1999, 121, 791-799. doi:10.1021/ja983222u

52. Grela, K.; Harutyunyan, S.; Michrowska, A. Angew. Chem., Int. Ed. 2002, 41, 4038-4040. doi:10.1002/1521-3773(20021104)41:21<4038::AID-ANIE4038>3.0.CO ;2-0

53. Dowden, J.; Savovic, J. Chem. Commun. 2001, 2, 37-38. doi:10.1039/b007304k 
54. Garber, S. B.; Kingsbury, J. S.; Gray, B. L.; Hoveyda, A. H. J. Am. Chem. Soc. 2000, 122, 8168-8179. doi:10.1021/ja001179g

55. Gessler, S.; Randl, S.; Blechert, S. Tetrahedron Lett. 2000, 41, 9973-9976. doi:10.1016/S0040-4039(00)01808-6

56. Van Veldhuizen, J. J.; Garber, S. B.; Kingsbury, J. S.; Hoveyda, A. H. J. Am. Chem. Soc. 2002, 124, 4954-4955. doi:10.1021/ja020259c

57. La, D. S.; Sattely, E. S.; Ford, J. G.; Schrock, R. R.; Hoveyda, A. H. J. Am. Chem. Soc. 2001, 123, 7767-7778. doi:10.1021/ja010684q

58. Connon, S. J.; Rivard, M.; Zaja, M.; Blechert, S. Adv. Synth. Catal. 2003, 345, 572-575. doi:10.1002/adsc.200202201

59. Michrowska, A.; Bujok, R.; Harutyunyan, S.; Sashuk, V.; Dolgonos, G.; Grela, K. J. Am. Chem. Soc. 2004, 126, 9318-9325. doi:10.1021/ja048794v

60. Olszewski, T. K.; Bieniek, M.; Skowerski, K.; Grela, K. Synlett 2013, 24, 903-919. doi:10.1055/s-0032-1318497

61. Honda, T.; Namiki, H.; Kaneda, K.; Mizutani, H. Org. Lett. 2004, 6 , 87-89. doi:10.1021/ol0361251

62. Skowerski, K.; Białecki, J.; Tracz, A.; Olszewski, T. K. Green Chem. 2014, 16, 1125-1130. doi:10.1039/C3GC41943F

63. Michrowska, A.; Gułajski, L.; Kaczmarska, Z.; Mennecke, K.; Kirschning, A.; Grela, K. Green Chem. 2006, 8, 685-688. doi:10.1039/b605138c

64. Kuhn, K. M.; Bourg, J.-B.; Chung, C. K.; Virgil, S. C.; Grubbs, R. H. J. Am. Chem. Soc. 2009, 131, 5313-5320. doi:10.1021/ja900067c

65. Zaman, S.; Abell, A. D. Tetrahedron Lett. 2009, 50, 5340-5343. doi:10.1016/j.tetlet.2009.07.022

66. Kniese, M.; Meier, M. A. R. Green Chem. 2010, 12, 169-173. doi:10.1039/B921126H

67. Skowerski, K.; Szczepaniak, G.; Wierzbicka, C.; Gułajski, Ł.; Bieniek, M.; Grela, K. Catal. Sci. Technol. 2012, 2, 2424-2427. doi:10.1039/c2cy20320k

68. Occhipinti, G.; Hansen, F. R.; Törnroos, K. W.; Jensen, V. R. J. Am. Chem. Soc. 2013, 135, 3331-3334. doi:10.1021/ja311505v

69. Skowerski, K.; Kasprzycki, P.; Bieniek, M.; Olszewski, T. K. Tetrahedron 2013, 69, 7408-7415. doi:10.1016/j.tet.2013.06.056

70. Love, J. A.; Morgan, J. P.; Trnka, T. M.; Grubbs, R. H. Angew. Chem., Int. Ed. 2002, 41, 4035-4037. doi:10.1002/1521-3773(20021104)41:21<4035::AID-ANIE4035>3.0.CO ;2-I

71. Zhang, K.; Cui, J.; Lackey, M.; Tew, G. N. Macromolecules 2010, 43, 10246-10252. doi:10.1021/ma101950f

72. Jafarpour, L.; Schanz, H.-J.; Stevens, E. D.; Nolan, S. P. Organometallics 1999, 18, 5416-5419. doi:10.1021/om990587u

73. Fürstner, A.; Guth, O.; Düffels, A.; Seidel, G.; Liebl, M.; Gabor, B.; Mynott, R. Chem. - Eur. J. 2001, 7, 4811-4820. doi:10.1002/1521-3765(20011119)7:22<4811::AID-CHEM4811>3.0.C O;2-P

74. Schmidt, B.; Wildemann, H. J. Chem. Soc., Perkin Trans. 12000 , 2916-2925. doi:10.1039/b004302h

75. Fürstner, A.; Radkowski, K. Chem. Commun. 2001, 2, 671-672. doi:10.1039/b101148k

76. Fürstner, A.; Grabowski, J.; Lehmann, C. W.; Kataoka, T.; Nagai, K. ChemBioChem 2001, 2, 60-68. doi:10.1002/1439-7633(20010105)2:1<60::AID-CBIC60>3.0.CO;2-P

77. Boeda, F.; Bantreil, X.; Clavier, H.; Nolan, S. P. Adv. Synth. Catal. 2008, 350, 2959-2966. doi:10.1002/adsc.200800495

78. Clavier, H.; Nolan, S. P. Chem. - Eur. J. 2007, 13, 8029-8036. doi:10.1002/chem.200700256

79. Öfele, K.; Tosh, E.; Taubmann, C.; Herrmann, W. A. Chem. Rev. 2009, 109, 3408-3444. doi:10.1021/cr800516g
80. Urbina-Blanco, C. A.; Guidone, S.; Nolan, S. P.; Cazin, C. S. J. Ruthenium-Indenylidene and Other Alkylidene Containing Olefin Metathesis Catalysts. In Olefin metathesis: Theory and Practice; Grela, K., Ed.; John Wiley \& Sons, Inc.: Hoboken, NJ, U.S.A., 2014; pp 417-436. doi:10.1002/9781118711613.ch15

81. Fürstner, A.; Thiel, O. R. J. Org. Chem. 2000, 65, 1738-1742. doi:10.1021/jo991611g

82. Dorta, R.; Kelly, R. A., III; Nolan, S. P. Adv. Synth. Catal. 2004, 346, 917-920. doi:10.1002/adsc.200404047

83. Ablialimov, O.; Kędziorek, M.; Malińska, M.; Woźniak, K.; Grela, K. Organometallics 2014, 33, 2160-2171. doi:10.1021/om4009197

84. Bantreil, X.; Schmid, T. E.; Randall, R. A. M.; Slawin, A. M. Z.; Cazin, C. S. J. Chem. Commun. 2010, 46, 7115-7117. doi:10.1039/c0cc02448a

85. Bantreil, X.; Poater, A.; Urbina-Blanco, C. A.; Bidal, Y. D.; Falivene, L.; Randall, R. A. M.; Cavallo, L.; Slawin, A. M. Z.; Cazin, C. S. J. Organometallics 2012, 31, 7415-7426. doi:10.1021/om300703p

86. Guidone, S.; Songis, O.; Nahra, F.; Cazin, C. S. J. ACS Catal. 2015, 5, 2697-2701. doi:10.1021/acscatal.5b00197

87. Opstal, T.; Verpoort, F. J. Mol. Catal. A: Chem. 2003, 200, 49-61. doi:10.1016/S1381-1169(03)00099-2

88. Opstal, T.; Verpoort, F. Synlett 2002, 935-941. doi:10.1055/s-2002-31892

89. Opstal, T.; Verpoort, F. Synlett 2003, 314-320. doi:10.1055/s-2003-37106

90. Opstal, T.; Verpoort, F. Tetrahedron Lett. 2002, 43, 9259-9263. doi:10.1016/S0040-4039(02)02233-5

91. Drozdzak, R.; Ledoux, N.; Allaert, B.; Dragutan, I.; Dragutan, V.; Verpoort, F. Cent. Eur. J. Chem. 2005, 3, 404-416. doi:10.2478/BF02479271

92. Drozdzak, R.; Allaert, B.; Ledoux, N.; Dragutan, I.; Dragutan, V.; Verpoort, F. Adv. Synth. Catal. 2005, 347, 1721-1743. doi:10.1002/adsc.200404389

93. Opstal, T.; Verpoort, F. Angew. Chem., Int. Ed. 2003, 42, 2876-2879. doi:10.1002/anie.200250840

94. De Clercq, B.; Verpoort, F. J. Organomet. Chem. 2003, 672, 11-16. doi:10.1016/S0022-328X(03)00055-X

95. Chang, S.; Jones, L., II; Wang, C.; Henling, L. M.; Grubbs, R. H. Organometallics 1998, 17, 3460-3465. doi:10.1021/om970910y

96. De Clercq, B.; Verpoort, F. Adv. Synth. Catal. 2002, 344, 639-648.

97. De Clercq, B.; Verpoort, F. Tetrahedron Lett. 2002, 43, 9101-9104 doi:10.1016/S0040-4039(02)02247-5

98. Vila, A. M. L.; Monsaert, S.; Drozdzak, R.; Wolowiec, S.; Verpoort, F. Adv. Synth. Catal. 2009, 351, 2689-2701. doi:10.1002/adsc. 200900477 


\section{License and Terms}

This is an Open Access article under the terms of the Creative Commons Attribution License

(http://creativecommons.org/licenses/by/2.0), which permits unrestricted use, distribution, and reproduction in any medium, provided the original work is properly cited.

The license is subject to the Beilstein Journal of Organic Chemistry terms and conditions:

(http://www.beilstein-journals.org/bjoc)

The definitive version of this article is the electronic one which can be found at:

doi:10.3762/bjoc.11.221 